\title{
The Bortoluzzi Mud Volcano (Ionian Sea, Italy) and its potential for tracking the seismic cycle of active faults
}

\author{
Marco Cuffaro $^{1}$, Andrea Billi ${ }^{1}$, Sabina Bigi ${ }^{2}$, Alessandro Bosman ${ }^{1}$, Cinzia G. Caruso ${ }^{3}$, Alessia Conti ${ }^{2}$, \\ Andrea Corbo $^{3}$, Antonio Costanza ${ }^{4}$, Giuseppe D’Anna ${ }^{4}$, Carlo Doglioni ${ }^{2,5}$, Paolo Esestime ${ }^{6}$, Gioacchino Fertitta $^{4}$, \\ Luca Gasperini $^{7}$, Francesco Italiano ${ }^{3}$, Gianluca Lazzaro ${ }^{3}$, Marco Ligi ${ }^{7}$, Manfredi Longo ${ }^{3}$, Eleonora Martorelli $^{1}$, \\ Lorenzo Petracchini ${ }^{1}$, Patrizio Petricca ${ }^{2}$, Alina Polonia ${ }^{7}$, and Tiziana Sgroi ${ }^{5}$ \\ ${ }^{1}$ Istituto di Geologia Ambientale e Geoingegneria, CNR, Rome, Italy \\ ${ }^{2}$ Dipartimento di Scienze della Terra, Sapienza Universitá di Roma, Rome, Italy \\ ${ }^{3}$ Istituto Nazionale di Geofisica e Vulcanologia, Palermo, Italy \\ ${ }^{4}$ Istituto Nazionale di Geofisica e Vulcanologia, Gibilmanna, Italy \\ ${ }^{5}$ Istituto Nazionale di Geofisica e Vulcanologia, Rome, Italy \\ ${ }^{6}$ Spectrum Geo Ltd, Woking, UK \\ ${ }^{7}$ Istituto di Scienze Marine, CNR, Bologna, Italy
}

Correspondence: Andrea Billi (andrea.billi@cnr.it)

Received: 26 October 2018 - Discussion started: 10 December 2018

Revised: 16 April 2019 - Accepted: 25 April 2019 - Published: 4 June 2019

\begin{abstract}
The Ionian Sea in southern Italy is at the center of active interaction and convergence between the Eurasian and African-Adriatic plates in the Mediterranean. This area is seismically active with instrumentally and/or historically recorded $M_{\mathrm{w}}>7.0$ earthquakes, and it is affected by recently discovered long strike-slip faults across the active Calabrian accretionary wedge. Many mud volcanoes occur on top of the wedge. A recently discovered one (called the Bortoluzzi Mud Volcano or BMV) was surveyed during the Seismofaults 2017 cruise (May 2017). High-resolution bathymetric backscatter surveys, seismic reflection profiles, geochemical and earthquake data, and a gravity core are used here to geologically, geochemically, and geophysically characterize this structure. The BMV is a circular feature $\simeq 22 \mathrm{~m}$ high and $\simeq 1100 \mathrm{~m}$ in diameter with steep slopes (up to a dip of $22^{\circ}$ ). It sits atop the Calabrian accretionary wedge and a system of flower-like oblique-slip faults that are probably seismically active as demonstrated by earthquake hypocentral and focal data. Geochemistry of water samples from the seawater column on top of the BMV shows a significant contamination of the bottom waters from saline (evaporite-type) $\mathrm{CH}_{4}$-dominated crustal-derived fluids similar to the fluids collected from a mud volcano located on the Calabria main-
\end{abstract}

land over the same accretionary wedge. These results attest to the occurrence of open crustal pathways for fluids through the BMV down to at least the Messinian evaporites at about $-3000 \mathrm{~m}$. This evidence is also substantiated by helium isotope ratios and by comparison and contrast with different geochemical data from three seawater columns located over other active faults in the Ionian Sea area. One conclusion is that the BMV may be useful for tracking the seismic cycle of active faults through geochemical monitoring. Due to the widespread diffusion of mud volcanoes in seismically active settings, this study contributes to indicating a future path for the use of mud volcanoes in the monitoring and mitigation of natural hazards.

\section{Introduction}

Mud volcanoes are ubiquitous structures on the Earth's surface in both marine and continental settings and form due to a variety of causes, most of which are amenable to clayand fluid-rich subsurface levels in which overpressure contributes to driving the ascent of mixed and liquefied clay, water, and gases (e.g., $\mathrm{CO}_{2}, \mathrm{CH}_{4}$, and $\mathrm{N}$ ), with the consequent 
formation of a conical or conical-trunk landform (Etiope and Milkov, 2004; Planke et al., 2003; León et al., 2007; Ceramicola et al., 2014; Sella et al., 2014). Mud volcanoes may therefore be taken as markers of overpressure-related geofluid circulation, efflux, and ascent (Bertoni and Cartwright, 2015; Kirkham et al., 2017).

Many mud volcanoes occur on active accretionarysedimentary prisms (Cita, 1981; Kopf, 2002; Panieri et al., 2013; Ceramicola et al., 2014), where their degassing activity is at least in part connected with active compression and associated faulting and fracturing (Camerlenghi et al., 1995; Kopf, 2002; Chamot-Rooke et al., 2005; Mazzini et al., 2007; Panieri et al., 2013). It is also noteworthy that, in these active tectonic settings, the longevity of mud volcanoes may even exceed $1 \mathrm{Ma}$ (Cita et al., 1989; Camerlenghi et al., 1992, 1995; Robertson, 1996; Kopf et al., 1998; Praeg et al., 2009; Somoza et al., 2012). All together the known submarine mud volcanoes release about $27 \mathrm{Mt}$ methane $\mathrm{a}^{-1}$ (plus other gases; Milkov, 2004; Etiope and Milkov, 2004).

The Ionian Sea between eastern Sicily and southern Calabria (Italy; Fig. 1) hosts an active accretionary prism (the Calabrian Arc; Minelli and Faccenna, 2010; Polonia et al., 2011, 2016; Gutscher et al., 2016), in which both prismparallel thrusts and across-prism strike- and oblique-slip faults are active. Some of these faults are the source structures of some of the most devastating earthquakes and tsunamis in southern Italy and the entire Mediterranean (Polonia et al., 2012; Totaro et al., 2013; Doglioni et al., 2012). Among other devastating events in the Ionian Sea area, we recall the $1908\left(M_{\mathrm{W}} 7.2\right), 1783\left(M_{\mathrm{w}} 6.9\right), 1693$ $\left(M_{\mathrm{W}} 7.4\right), 1169\left(M_{\mathrm{w}} 6.6\right)$, and $362 \mathrm{CE}\left(M_{\mathrm{W}} 6.6\right)$ earthquakes and tsunamis, which caused damage, devastation, and death (more than 80000 deaths in 1908) in eastern Sicily and southern Calabria (Locati et al., 2016). Although such events have been studied by many authors for the great impact they produced, the origins (zone and generation mechanism) are still heavily debated for both earthquakes and tsunamis. The faults that generated such earthquakes are not yet known as it is unknown whether the associated tsunamis were generated directly by earthquakes (i.e., fault dislocation of the seabed) or indirectly by seismically triggered submarine slides (Valensise and Pantosti, 1992; Billi et al., 2008, 2010; Polonia et al., 2016).

To better define the seismic behavior of active faults in the Ionian Sea, during the Seismofaults 2017 and 2018 marine surveys (May 2017 and 2018, respectively; http://www. seismofaults.it, last access: 15 May 2019), we deployed 11 sea-bottom seismometers (OBS/H) and two sea-bottom multiparametric geochemical-geophysical sensors. At the time of writing of this paper, some of these devices are still operating on the sea bottom, while data from the recovered devices are being processed and are therefore not available for publication. One of the aims of this project (Seismofaults) and related surveys was to contribute to the advancement of the science of earthquake forecasting. For this reason, we de- ployed the multiparametric sensors (i.e., to detect anomalous degassing prior to earthquakes), collected seawater column samples along and far away from (active) faults, and searched for new fluid-venting structures such as mud volcanoes. The activity of some of these latter structures may be partly connected to (seismic) faulting (Martinelli et al., 1995; Polonia et al., 2011; Capozzi et al., 2012; Panieri et al., 2013; Ceramicola et al., 2014). For instance, Martinelli and Ferrari (1991) and Martinelli et al. (1995) recorded radon anomalies $\left({ }^{222} \mathrm{Rn}\right)$ in the liquid phase of some mud volcanoes from the northern Apennines (Italy) before and during low-magnitude earthquakes $(\leq 2.5)$ that occurred nearby in 1986 and 1987 . Again in the northern Apennines, Lupi et al. (2015) recorded potential precursory seismological signals $10 \mathrm{~min}$ before an $M_{\mathrm{w}} 4.7$ earthquake in a monitored mud-volcanic field. Discovering and monitoring such structures may therefore be the key, in the future, to better understanding the seismic cycles and possible accompanying or precursory processes and phenomena, such as anomalous fluid discharge, from mud volcanoes (Martinelli and Ferrari, 1991; Martinelli et al., 1995; Kopf, 2002; Mazzini and Etiope, 2017). A link between the frequency of eruption of some mud volcanoes and seismic activity has often been documented (Deville and Guerlais, 2009; Manga et al., 2009). An example is the $5 \mathrm{~km}$ long mudflow emitted by the Kandewari mud volcano (Pakistan) following the 2001 Gujarat-Bhuj $M_{\mathrm{w}} 7.7$ earthquake (IndiaPakistan; Delisle et al., 2002). It is also true, however, that many active mud volcanoes do not seem to manifestly react to nearby earthquakes. Our aim in this article is not to find a link between earthquakes and the activity of mud volcanoes but to understand whether a mud volcano that seems inactive or poorly active can constitute an open and preferential pathway for possible geochemical precursors of earthquakes. Whether these precursors truly manifest before an earthquake is a different task that has to be accomplished with specific monitoring, as we will explain in the Discussion section. Our aim is nonetheless relevant for many geoscientists as noteworthy examples of earthquake geochemical precursors are documented in many previous works (Wakita et al., 1988; Igarashi et al., 1995; Claesson et al., 2004; Huang and Ding, 2012; Inan et al., 2012; Skelton et al., 2014, 2019; Sano et al., 2016; Barberio et al., 2017; Petitta et al., 2018; Boschetti et al., 2019) and are very promising for the science of earthquake forecasting.

Following the abovementioned reasons and aims, during the Seismofaults 2017 scientific cruise in the Ionian Sea (Fig. 1), we surveyed a mud volcano that was recently signalled on the Calabrian accretionary prism by Gutscher et al. (2017) and Loher et al. (2018) but never analyzed in detail. We performed a multidisciplinary analysis on this feature, including high-resolution multibeam bathymetry, highfrequency chirp-sonar profiling, physical and chemical analyses of the water column above the mud volcano, and gravity coring on one side of this structure. Based on these new data integrated with previous ones, we interpret the recently dis- 


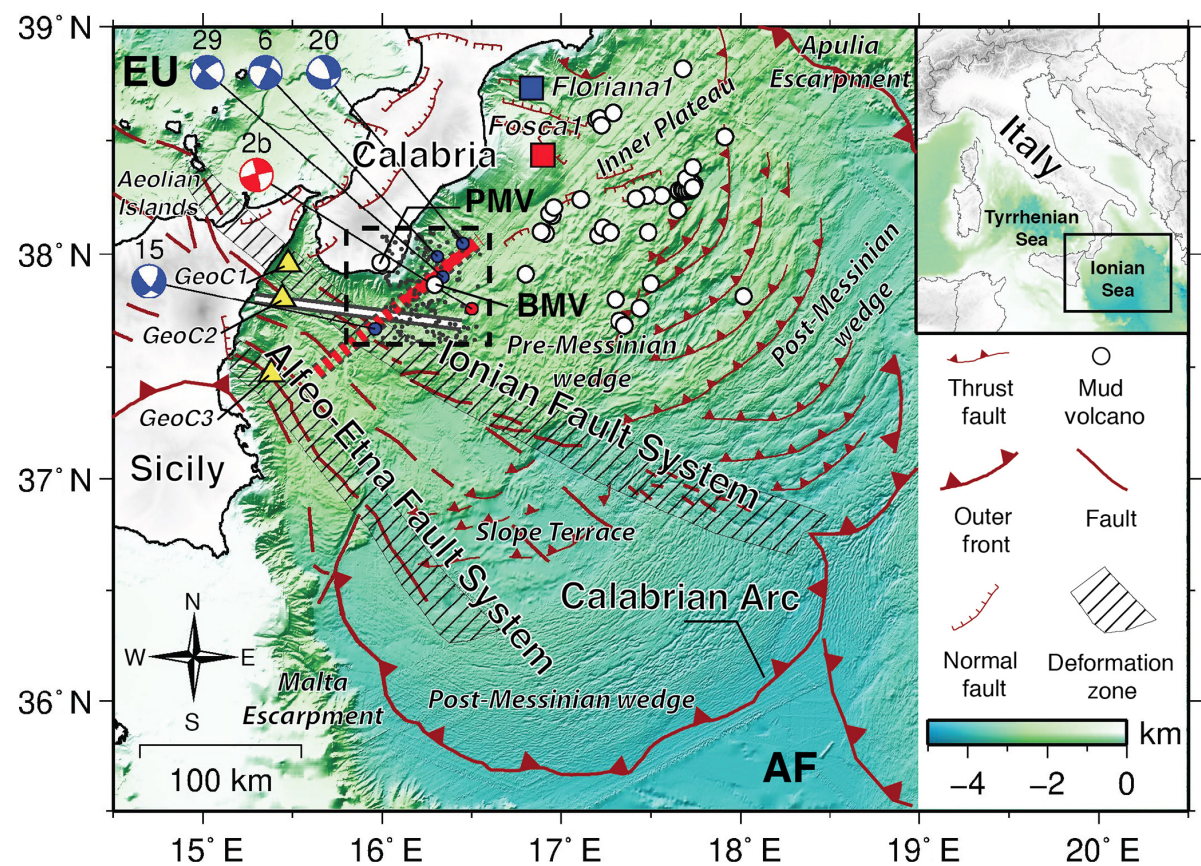

Figure 1. Bathymetric map of the Ionian Sea (southern Italy) with main faults, mud volcanoes, earthquakes, tracks of multichannel seismic profiles, and the location of the Fosca 1 (red square) and Floriana 1 (blue square) offshore wells. Locations of mud volcanoes (except the Palizzi mud volcano, PMV; inland Calabria) are from Loher et al. (2018). The Bortoluzzi Mud Volcano is indicated as BMV. The thick white line corresponds to the CROP M-31 multichannel seismic profile (Fig. 10a). The dashed red line and solid red line are the CA99-215 multichannel profile (Fig. 10b) and its close-up view shown in Fig. 10c, respectively. Earthquake epicenters (epicenters are indicated by thin grey dots and focal mechanisms by beach balls) surrounding the BMV area were relocated in this work, whereas focal mechanisms are from the European-Mediterranean Regional Centroid-Moment Tensor (RCMT) catalog (http://rcmt2.bo.ingv.it/, last access: 15 May 2019) (red beach ball) and from previous papers (blue beach balls) by Orecchio et al. (2014) and Polonia et al. (2016). Faults are principally from Polonia et al. (2011, 2016) and Bortoluzzi et al. (2017). The black box is the location of Fig. 2. AF stands for African Plate, whereas EU is for Eurasia Plate. GeoC1, GeoC2, and GeoC3 are locations of seawater column sampling.

covered mud volcano within the framework of the (seismically) active accretionary prism of Calabria and eventually provide some implications for future marine research and monitoring of the seismic cycle in marine areas. As mentioned above, our main aim is not only to characterize the mud volcano but also to provide a contribution toward a potential and feasible future path for the use of these ubiquitous structures in favor of the monitoring and mitigation of natural hazards. As the mud volcano studied in this paper had already been observed years ago by our colleague Giovanni Bortoluzzi in one of his numerous marine surveys, we name this structure the Bortoluzzi Mud Volcano (BMV) to honor his memory and fruitful life spent sailing for science over the Mediterranean Sea and the oceans. The BMV was selected for this study mainly for its proximity to the coast, particularly to seismically hazardous regions (southern Calabria and eastern Sicily; Fig. 1), and for its location on top of a seismically active fault system, as we will show below.

\section{Geological setting}

The BMV is located on top of the Calabrian Arc (Ionian Sea; Fig. 1) that has developed along the Africa-Eurasia plate boundary in the center of the Mediterranean Sea. The arc belongs to the eastward-retreating Apennines subduction system connecting the NW-SE-trending Apennines with the EW-oriented Maghrebian thrust-fold belt (Patacca and Scandone, 2004). In particular, the Calabrian Arc has developed on top of a NW-dipping subduction system with the Ionian lithosphere sinking toward the NW beneath the Tyrrhenian lithosphere. This subduction system is also characterized by an active volcanic arc (the Aeolian Islands in the southeastern Tyrrhenian) and a well-defined Wadati-Benioff zone (Wortel and Spakman, 2000), with earthquakes descending to nearly $500 \mathrm{~km}$ of depth beneath the Aeolian Islands on the Tyrrhenian lithosphere. The Africa-Eurasia convergence is active in this area at a very slow rate $\left(5 \mathrm{~mm} \mathrm{yr}^{-1}\right.$ or even less), as documented by recent global positioning system (GPS) studies (Serpelloni et al., 2007; Billi et al., 2011; Palano et al., 2012; Palano et al., 2015). The external part of the arc is represented by a $300 \mathrm{~km}$ wide accretionary complex bounded to 
the south by the outer deformation front and laterally by two major structural discontinuities: the Malta escarpment to the southwest and the Apulia escarpment to the northeast. To the northwest (i.e., toward the Calabria region), the accretionary wedge is significantly thickened (Cernobori et al., 1996), whereas it tapers away toward the southeast in the Mediterranean Sea. The wedge is segmented along strike in different structural domains by NW-trending structural discontinuities. The compartments are characterized by different rheologies and deformation styles (Polonia et al., 2011). In particular, three main morpho-structural domains can be identified in the subduction complex: (i) the post-Messinian accretionary wedge; (ii) the pre-Messinian accretionary wedge; and (iii) the inner plateau. Structural styles and seafloor morphologies vary in these four compartments in correlation with different tectonic processes that include frontal accretion, out-of-sequence thrusting, underplating, and complex faulting.

In the Calabrian Arc, the very low tapered (taper angle about $1.5^{\circ}$ ) outermost accretionary wedge is a salt-bearing complex developed during and after the Messinian salinity crisis (Fig. 1). Frontal accretion of the arc is active in this southern region over a shallow basal detachment located within or at the base of the Messinian evaporites. The inner wedge, which is located toward the NW at the rear of the post-Messinian accretionary complex, consists of preMessinian clastic sediments. The basal thrust of the inner wedge is located on top of Cretaceous sediments and/or at the transition with the basement. Moreover, the inner wedge is bounded toward the NW by an inner deformation front, representing the transition between the strongly deformed accretionary wedge to the SE and a less deformed inner plateau to the NW. This plateau is, however, dissected by long normal and strike-slip fault zones mostly striking NW-SE. The inner plateau is characterized by chaotic units (Rossi and Sartori, 1981) and many mud volcanoes (Praeg et al., 2009; Ceramicola et al., 2014; Gutscher et al., 2017; Loher et al., 2018) including the BMV that is studied in this work.

As mentioned above, the Calabrian accretionary wedge is cut across (NW-SE) by a set of long faults or deformation zones (Fig. 1). Most of these tectonic features are active and characterized by strike-slip to transtensional or transpressional (oblique) kinematics. At a broad scale, the sense of horizontal shear along these zones is usually right-lateral (Minelli and Faccenna, 2010; Polonia et al., 2011, 2016, 2017; Gallais et al., 2012, 2013; Gutscher et al., 2016; Bortoluzzi et al., 2017). Below, we show that the BMV is located on top of one of these oblique-slip features crossing the Calabrian accretionary wedge.

\section{Methods and data}

\subsection{Rationale}

As mentioned above, the main target of this work is the BMV located at $37^{\circ} 53^{\prime} 01^{\prime \prime} \mathrm{N}$ and $16^{\circ} 16^{\prime} 50^{\prime \prime} \mathrm{E}$ in the Ionian Sea (Fig. 1). During the Seismofaults 2017 cruise in the BMV area, we acquired high-resolution multibeam bathymetry (bathymetry, backscatter, and water column), chirp seismic profiles, physical and geochemical data on the seawater column, and a sediment gravity core. These data are described below together with the related methods of acquisition and with a reprocessed and unpublished seismic reflection profile whose track is only about $300 \mathrm{~m}$ away from the BMV. We integrated the abovementioned geological-geophysicalgeochemical evidence with previously published data and with data from other databases (e.g., earthquake data). All data used are reported in the figures and tables of this paper and the related Supplement. Moreover, with this paper, we release $4970 \mathrm{~km}^{2}$ of newly acquired (during the Seismofaults 2017 cruise) high-resolution bathymetric data in the Ionian Sea, including the BMV area (Fig. S1 in the Supplement).

\subsection{Earthquakes}

To understand whether the study area (BMV) is seismically active, we analyzed the crustal seismicity (depth $\leq$ $40 \mathrm{~km}$ ) occurring in the study area and recorded by the Osservatorio Nazionale Terremoti of the Istituto Nazionale di Geofisica e Vulcanologia (http://cnt.rm.ingv.it/, last access: 15 May 2019) from 1985 to 2017. We collected the arrival time data from the Italian Seismic Catalog (ISC 1985-2002; available online at http://csi.rm.ingv.it/, last access: 15 May 2019; Castello et al., 2006) and the Italian Seismic Bulletin (ISB 2003-2012; available online at http: //bollettinosismico.rm.ingv.it/, last access: 15 May 2019). Then, one of us (Tiziana Sgroi) manually picked the most recent earthquakes (2013-2017) following the same procedure adopted by the analysts of ISC 1985-2002 and ISB 20032012. Combining the picked arrival time data with the arrival time data from the analyzed bulletins, Tiziana Sgroi relocated all earthquakes (Table S1 in the Supplement). Moreover, to understand the kinematics of the seismic faulting, we collected earthquake focal mechanisms (Table S2) from the European-Mediterranean Regional Centroid-Moment Tensor (RCMT) catalog (http://rcmt2.bo.ingv.it/, last access: 15 May 2019) and from previous papers by Orecchio et al. (2014) and Polonia et al. (2016). Earthquake data (Tables S1 and S2) are shown in map view in Figs. 1 and $2 \mathrm{a}$ and in vertical cross-sectional view in Fig. 2 b.

\subsection{Bathymetry and geomorphology}

We carried out the high-resolution multibeam bathymetric survey (Figs. 3, 4 and S1) using a multibeam Teledyne RESON SeaBat $7160(41-47 \mathrm{kHz})$ echosounder characterized 


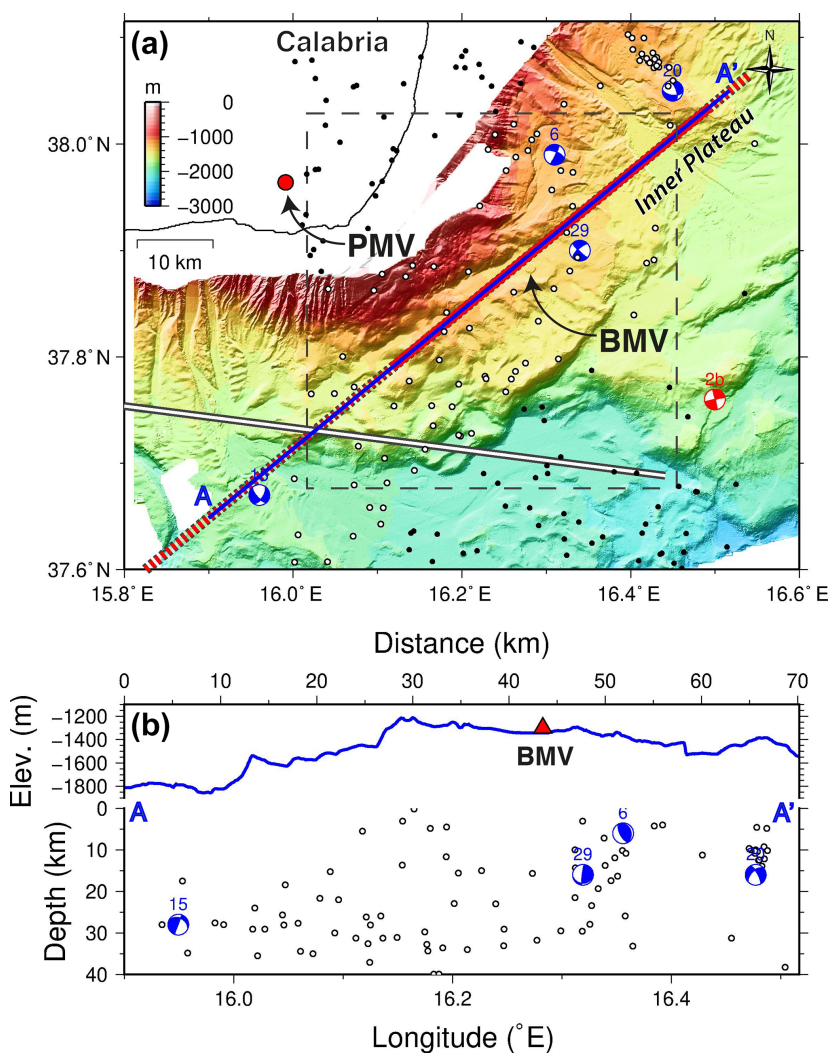

Figure 2. (a) High-resolution bathymetry (see location in Fig. 1) of the Calabrian offshore, Ionian Sea, with the location of the BMV. Earthquake epicenters and focal mechanisms (Tables S1 and S2) surrounding the BMV area are shown as dots (black and white) and beach balls, respectively. Focal mechanisms (Table S2) are from the European-Mediterranean Regional Centroid-Moment Tensor (red beach ball) catalog (http://rcmt2.bo.ingv.it/, last access: 15 May 2019) and from previous papers (blue beach balls) by Orecchio et al. (2014) and Polonia et al. (2016). White dots represent the selected seismic events at an arbitrary distance of $12 \mathrm{~km}$ to be projected along the transect A-A' (blue line). The thick white, dashed red, and solid red lines respectively correspond to the CROP M-31 profile (Fig. 10b), CA99-215 profile (Fig. 10a), and a close-up view of the CA99-215 profile (Fig. 10c). The black dashed box is the location of Fig. 3. (b) A-A' vertical cross-sectional transect (see track in Fig. 2a) showing a perpendicular projection (onto the transect) of earthquake hypocenters and focal mechanisms for the BMV area. The blue line is the corresponding seafloor profile, over which the projected location of the BMV (red triangle) is shown.

by footprint size of $1^{\circ} \times 1^{\circ}$. We identified precise positioning through differential GPS (accuracy $\pm 0.5 \mathrm{~m}$ ), while we derived sound velocity profiles from multiple conductivitytemperature-depth (CTD) casts (Sea-Bird 911plus) to ray trace the acoustic wave along the water column. We processed multibeam data onboard using CARIS HIPS and Sips hydrographic software (Bosman et al., 2015). We used backscatter images and observations of raw data scattering along the water column (Fig. 5) to verify anomalies of am- plitude on the seafloor and along the water column. Eventually, we compared some geometrical features of the BMV with the same geometrical features from previously published databases of mud volcanoes (Kioka and Ashi, 2015; Kirkham et al., 2017, Fig. 6).

\subsection{Single-channel chirp seismic reflection profiles}

During the Seismofaults 2017 survey, to define the local geological setting and a high-resolution seismic stratigraphy of the BMV and surrounding area, we acquired a set of chirp seismic profiles (Figs. $7 \mathrm{~b}-\mathrm{d}, 8$, and $\mathrm{S} 2$ ) using a frequencymodulated source operating in the frequency range of 2$7 \mathrm{kHz}$ (Benthos Chirp III) and recorded with a $0.5-0.8 \mathrm{~s}$ sweep length. Maximum sub-bottom penetration is up to about $40 \mathrm{~ms}$ (in two-way travel time or TWT; corresponding to ca. $30 \mathrm{~m}$ if considering a seismic velocity of $1500 \mathrm{~m} \mathrm{~s}^{-1}$ ) and vertical resolution is about $0.7 \mathrm{~ms}$ (TWT; corresponding to ca. $0.5 \mathrm{~m}$ if considering a seismic velocity of $1500 \mathrm{~m} \mathrm{~s}^{-1}$ ). We processed the chirp profiles using the GeoSuite All Works software, applying time-varied gain, and the opensource software Seisprho (Gasperini and Stanghellini, 2009). Thicknesses and depths inferred from seismic profiles are described in two-way travel time (TWT; Figs. 7b-d and 8), with a seismic velocity of $1500 \mathrm{~m} \mathrm{~s}^{-1}$ being used to convert twoway travel time into depth. Seismic data interpretation was carried out through the Kingdom Suite software, also integrating the bathymetric data and a gravity core (Fig. 9).

\subsection{Sea-bottom gravity core}

We collected the SF17-01 core (Fig. 9; see core location in Fig. 7a) during the Seismofaults 2017 survey using a $1.2 \mathrm{t}$ gravity corer with coring pipes $6 \mathrm{~m}$ long. The location of the core was controlled through the aforementioned onboard differential GPS system (accuracy $\pm 0.5 \mathrm{~m}$ ). We analyzed the core sections through a multi-proxy approach involving high-resolution digital photographs and the determination of physical properties and sand content as deduced through the weight of selected samples. We also acquired high-resolution magnetic susceptibility (MS) through a core log system (Bartinghton model MS2, $100 \mathrm{~mm}$ loop sensor) with a sampling interval of $1.0 \mathrm{~cm}$.

\subsection{Multichannel seismic reflection profiles}

In this paper, we present two multiple-channel seismic reflection profiles and related interpretations (Fig. 10; see tracks in Fig. 1). The first profile (Fig. 10a) is CROP M-31 (Scrocca et al., 2003a) in the version interpreted by Polonia et al. (2016). The second one is CA99-215 in Fig. 10b that shows the regional seismic profile published in Polonia et al. (2016); its interpretation has been confirmed and integrated by a new reprocessing version kindly provided by Spectrum Geo Ltd (Fig. 10c and d; see also Fig. 2). 


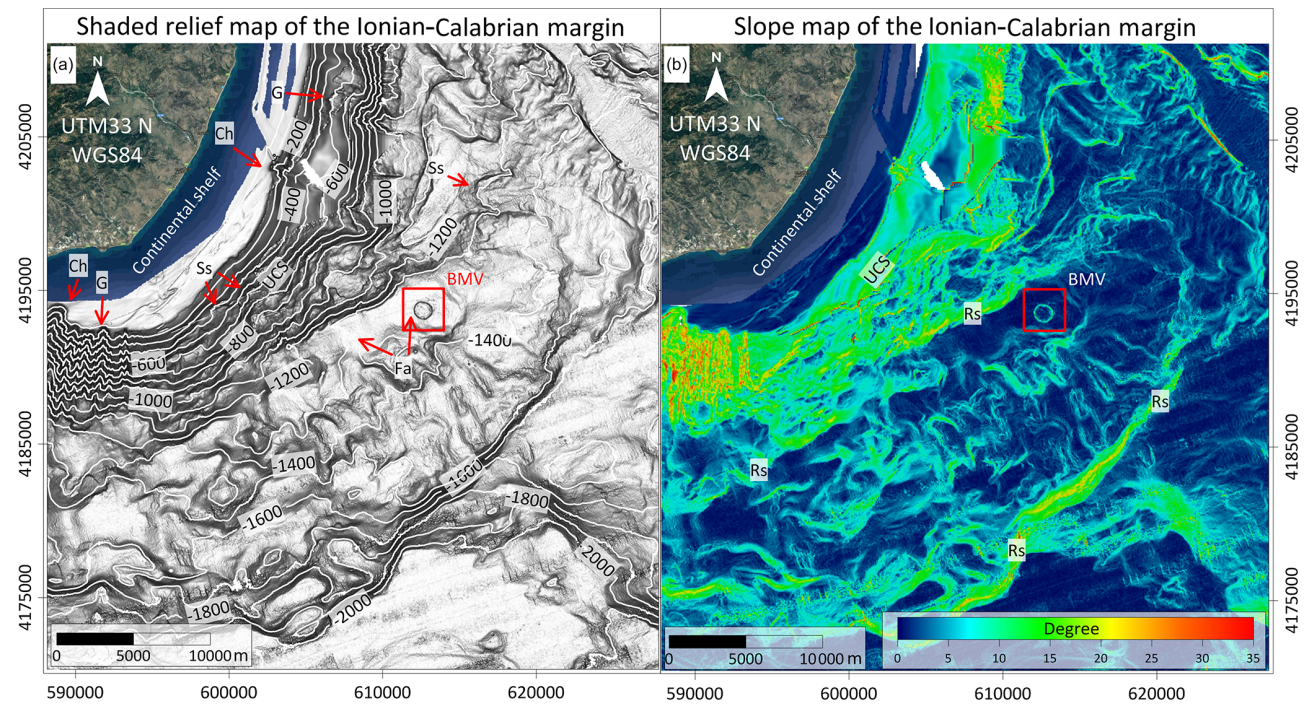

Figure 3. (a) Bathy-morphological map and main morphological features: canyon head (Ch), gullies (G), slide scars (Ss), regional scarps (Rs), and a $26 \mathrm{~km}^{2}$ flat area (Fa) are indicated. (b) Slope map of the upper portion of the continental slope (UCS) of the Calabrian-Ionian margin. Red square indicates the intraslope flat area hosting the circular high of the Bortoluzzi Mud Volcano (BMV). Location map is shown in Fig. 2a.
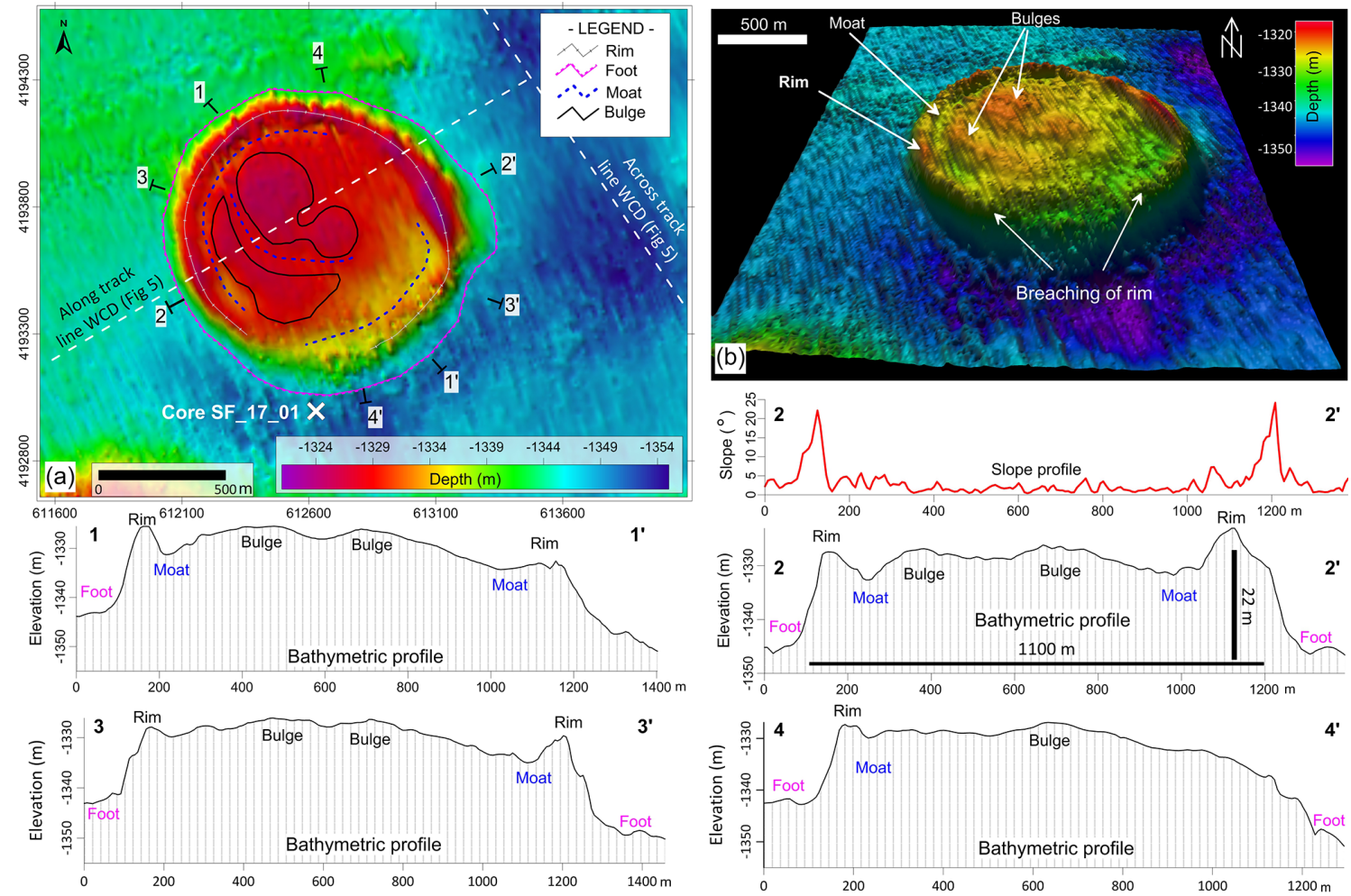

Figure 4. (a) Shaded relief map of the BMV with the main morphological features and location of bathymetric sections (1-1', 2-2', 3-3', and 4-4'). The bathymetric sections (vertical exaggeration $10 \times$ ) show the morphological features of the mud volcano with vertical slopes up to $28^{\circ}$ and two main concentric bulges separated by moats. (b) Digital 3-D perspective view of the BMV showing some main features and the breaching of the rim on the southern part of the BMV. In Fig. 4a, the track position (along and across) of the water column data (WCD) is shown (see Fig. 5). Two movies showing virtual flights over the BMV are available at http://www.seismofaults.it/index.php/videos (last access: 22 May 2019). 


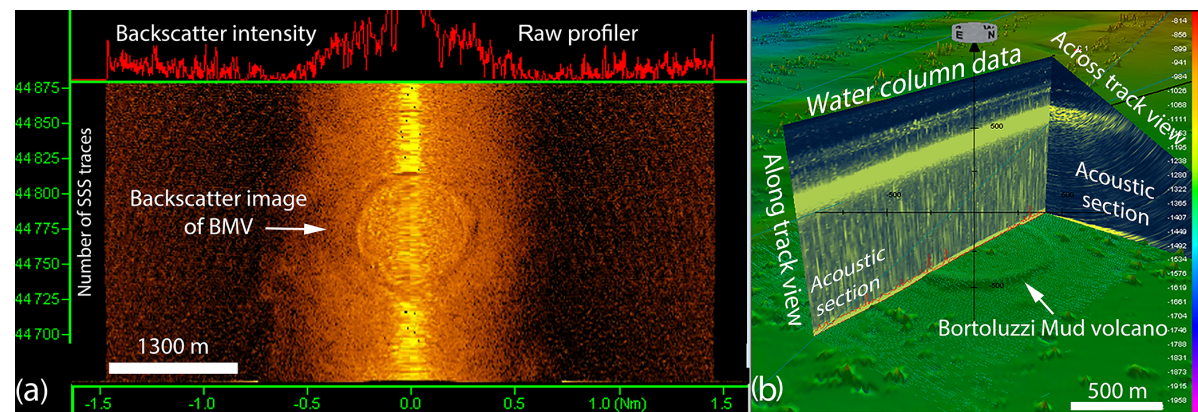

Figure 5. (a) Multibeam raw backscatter data of the seafloor. The raw backscatter data do not show amplitude anomalies on the top and around the BMW, indicating a mud homogeneous sedimentary cover. (b) Backscatter water column data recorded by multibeam system. The backscatter water column data do not show amplitude anomalies above the mud volcano, excluding the possibility of significant paroxysmal fluid-mud escape from the seafloor. Location tracks of the acoustic sections are shown in Fig. 4.

The CROP M-31 profile was acquired in 1994 in the framework of the CROP (CROsta Profonda) project (Scrocca et al., 2003b). The streamer used was analogic, $4500 \mathrm{~m}$ long, composed of 180 channels with a group interval of $25 \mathrm{~m}$, and towed at a depth of $12-14 \mathrm{~m}$. The total source volume was equal to $4882 \mathrm{in}^{3}$. The recording time length was $20 \mathrm{~s}$ and the shot interval was $50 \mathrm{~m}$, allowing for a fold of $4500 \%$ (Bertelli et al., 2003). In general, the applied processing sequences consisted of quality control, gain recovery, trace sum (optional), deconvolution, common midpoint sorting (CDP), velocity analysis (CVS), NMO correction, muting, multiple reflection attenuation, array simulation (optional), weighted stack, F-K filtering (optional), horizontal mixing (optional), time-variant filter, and equalization (Bertelli et al., 2003).

The CA99-215 profile was acquired in 1999 and reprocessed in 2001. Source volume was $3410 \mathrm{in}^{3}$, located at $6 \mathrm{~m}$ of depth, with a shot interval of $25 \mathrm{~m}$. The streamer used had a length of $6000 \mathrm{~m}$, towed at $8 \mathrm{~m}$ of depth, with a group interval of $12.5 \mathrm{~m}$, and a recording length of $8 \mathrm{~s}$. Reprocessing mainly consisted of a standard PSTM (pre-stack time migration) processing sequence, resulting in improved data quality.

Stratigraphic syntheses from the Fosca 1 and Floriana 1 wells (original well data are from the Videpi public database available online at https://unmig.sviluppoeconomico.gov.it/ videpi/videpi.asp, last access: 15 May 2019) are also presented (Fig. 10f) to help with the interpretation of the seismic profiles (see well location in Fig. 1).

\subsection{Geochemical features of four seawater columns}

During the Seismofaults 2017 survey, we sampled the seawater column at various depths in four localities of the Ionian Sea (Fig. 1 and Tables 1 and 2): namely, above the BMV and above the $\mathrm{GeoC} 1, \mathrm{GeoC} 2$, and $\mathrm{GeoC} 3$ localities that are along or near major presumably active fault zones (Polonia et al., 2012, 2016). We carried out vertical casts with Rosette and Niskin bottles to determine the geochemical features and dissolved gases at the sea bottom and along the water columns (Fig. 11 and Tables 1 and 2). Samples are compared with the local air-saturated seawater (ASSW) used as a benchmark.

The samples, specifically collected for the extraction of the whole gas phase for chemical and isotopic analyses, were stored in $240 \mathrm{~mL}$ Pyrex bottles sealed onboard using rubber or Teflon septa and purpose-built pliers and analyzed within 2 weeks. Details on the sampling methodology are reported in Italiano et al. (2009, 2014). During the cruise, the sampled bottles were stored upside down, keeping the necks with the rubber septa submerged in seawater until they were transferred to the laboratory. The collected seawater samples underwent laboratory procedures for both chemical (concentration of dissolved gas species) and isotopic (helium isotopes) determinations. In the laboratory, the dissolved gases were extracted after equilibrium was reached at constant temperature with a host gas (high-purity argon) injected in the sample bottle (see Italiano et al., 2009, 2014, for further details). The chemical analyses of $\mathrm{O}_{2}, \mathrm{~N}_{2}, \mathrm{CH}_{4}$, and $\mathrm{CO}_{2}$ were carried out by gas chromatography (Agilent 7800B equipped with a double thermal conductivity detector-flame ionization detector; TCD-FID) using argon as a carrier gas. Typical analytical uncertainties were within $\pm 5 \%$. He concentration was determined by mass spectrometry during ${ }^{3} \mathrm{He} /{ }^{4} \mathrm{He}$ analyses. Helium isotope and ${ }^{4} \mathrm{He} /{ }^{20} \mathrm{Ne}$ ratios were determined from gas fractions extracted following the same procedure described above and purified following the method described in the literature (Hilton, 1996; Sano and Wakita, 1988; Italiano et al., 2001). The isotopic analyses of the purified helium were performed using a static vacuum mass spectrometer (GVI5400TFT) that allows for the simultaneous detection of ${ }^{3} \mathrm{He}$ and ${ }^{4} \mathrm{He}$ ion beams, thereby keeping the ${ }^{3} \mathrm{He} /{ }^{4} \mathrm{He}$ error of measurement very low. The analytical method used also requires alternatively running one sample and one purified air shot used as an internal ${ }^{3} \mathrm{He} /{ }^{4} \mathrm{He}$ standard. Typical uncertainties in the range of atmospheric He-type samples are within $\pm 1 \%$. The ${ }^{4} \mathrm{He} /{ }^{20} \mathrm{Ne}$ ratios were calculated by the relative peak heights measured on the same mass spectrometer. 

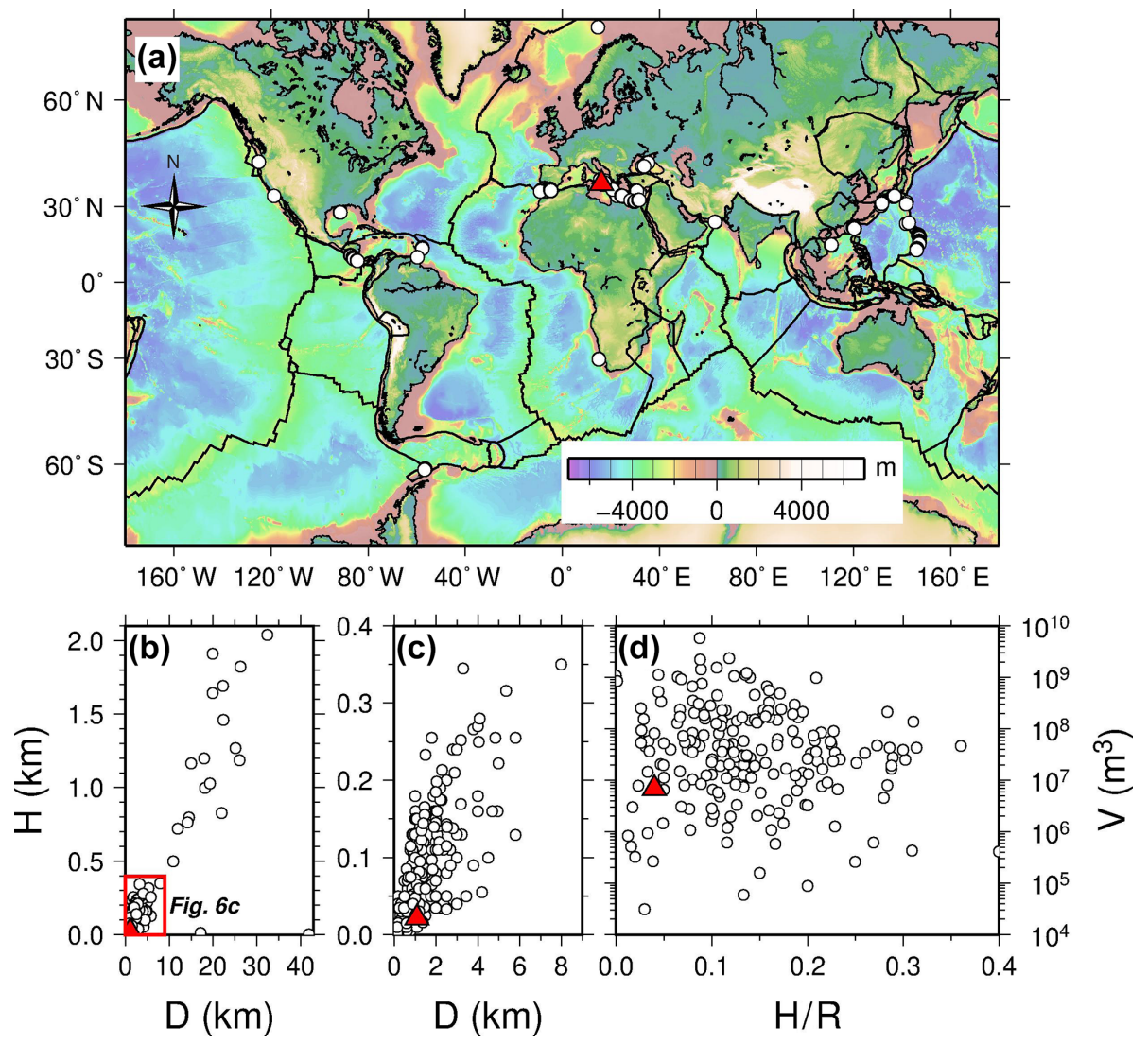

Figure 6. (a) Selection of the worldwide distribution of mud volcanoes (white dots) from the dataset reported by Kioka and Ashi (2015). In particular, 232 volcanoes with available mean diameter $D$ and height $H$ are shown. The red triangle is the BMV location. (b) Compilation of mud volcano diameter $D$ vs. height $H$, showing an approximately linear trend between increasing mud volcano diameters $(D)$ and heights $(H)$, excluding some exceptions. Along this trend, the BMV (red triangle) stands close the lower values. (c) Close-up view of a portion of the diagram in (b). (d) Compilation of volumes $V$ of mud volcanoes vs. $H / R$ (where $R$ is the radius of the volcano base), showing that the $H / R$ ratio is $\leq 0.4$ for all mud volcanoes, whereas there is a scatter distribution of mud volcano volumes, mostly ranging in the $10^{6}-10^{9} \mathrm{~m}^{3}$ interval. The BMV volume (red triangle) corresponds to $6.9 \times 10^{6} \mathrm{~m}^{3}$.

Table 1. Chemical composition of the seawater from the studied localities in the Ionian Sea (GeoC1, 2, and 3, and BMV). The chemical composition of the fluids sampled in a well adjacent to the Palizzi mud volcano (PMV) on the Calabria mainland is also reported. BDL: below detection limit, na: not analyzed.

\begin{tabular}{|c|c|c|c|c|c|c|c|c|c|c|c|c|c|c|}
\hline Sample & Date & $\begin{array}{r}\text { Depth } \\
(\mathrm{m})\end{array}$ & Latitude & Longitude & $\begin{array}{r}T \\
{ }^{\circ} \mathrm{C}\end{array}$ & $\mathrm{pH}$ & $\begin{array}{r}\mathrm{Na} \\
\left(\text { meq L }^{-1}\right)\end{array}$ & $\begin{array}{r}\mathrm{K} \\
\left(\text { meq }^{-1}\right)\end{array}$ & $\begin{array}{r}\mathrm{Mg} \\
\left(\text { meq }^{-1}\right)\end{array}$ & $\begin{array}{r}\mathrm{Ca} \\
\left(\mathrm{meq}^{-1}\right)\end{array}$ & $\begin{array}{r}\mathrm{Cl} \\
\left(\text { meq L }{ }^{-1}\right)\end{array}$ & $\begin{array}{r}\mathrm{Br} \\
\left(\text { meq L }^{-1}\right)\end{array}$ & $\begin{array}{r}\mathrm{SO}_{4} \\
\left(\text { meq } \mathrm{L}^{-1}\right)\end{array}$ & $\mathrm{HCO}_{3}$ \\
\hline $\mathrm{GeoC} 1$ & 05.17 .2017 & -1043 & $37^{\circ} 57^{\prime} 24.6^{\prime \prime}$ & $15^{\circ} 28^{\prime} 29.4^{\prime \prime}$ & 13.80 & 8.16 & 553 & 12.7 & 125 & 24.9 & 644 & 0.930 & 67.1 & 2.68 \\
\hline GeoC2 & 05.16 .2017 & -1649 & $37^{\circ} 43^{\prime} 10.8^{\prime \prime}$ & $15^{\circ} 26^{\prime} 40.8^{\prime \prime}$ & 13.79 & 8.37 & 552 & 12.7 & 125 & 25.2 & 637 & 0.999 & 66.5 & 2.68 \\
\hline GeoC3 & 05.16 .2017 & -2029 & $37^{\circ} 28^{\prime} 10.8^{\prime \prime}$ & $15^{\circ} 23^{\prime} 01.8^{\prime \prime}$ & 13.82 & 8.10 & 554 & 12.8 & 126 & 25.6 & 641 & BDL & 66.1 & 2.70 \\
\hline \multirow[t]{5}{*}{ BMV } & 05.18 .2017 & -1337 & $37^{\circ} 52^{\prime} 38.1^{\prime \prime}$ & $16^{\circ} 16^{\prime} 50.1^{\prime \prime}$ & 13.76 & 8.10 & 553 & 12.6 & 125 & 25.3 & 643 & 1.38 & 66.0 & 2.70 \\
\hline & & -1000 & & & 13.79 & 8.09 & 551 & 12.6 & 125 & 25.5 & 633 & 1.04 & 63.5 & 2.72 \\
\hline & & -500 & & & 14.25 & 8.16 & 555 & 12.6 & 125 & 25.5 & 645 & 1.04 & 65.8 & 2.70 \\
\hline & & -200 & & & 14.88 & 8.06 & 555 & 12.8 & 126 & 25.5 & 643 & 1.75 & 65.9 & 2.66 \\
\hline & & -50 & & & 15.91 & 8.07 & 552 & 12.7 & 125 & 25.5 & 638 & 1.09 & 66.0 & 2.71 \\
\hline Palizzi PMV & 10.06 .2003 & on land & $37^{\circ} 57^{\prime} 51.02^{\prime \prime}$ & $15^{\circ} 59^{\prime} 28.43^{\prime \prime}$ & na & na & 15.06 & 0.09 & 0.01 & 0.09 & 7.23 & BDL & 3.60 & na \\
\hline
\end{tabular}

Water samples of $100 \mathrm{~mL}$ were stored in PVC bottles for total alkalinity titration: $50 \mathrm{~mL}$ was filtered by a $0.45 \mu \mathrm{m}$ filter and acidified by $\mathrm{HNO}_{3} 0.1 \mathrm{~N}$ for cation $(\mathrm{Ca}, \mathrm{Mg}$, $\mathrm{Na}$, and $\mathrm{K}$ ) determination, whereas the nonacidified samples were collected for anion $\left(\mathrm{Cl}, \mathrm{F}\right.$, and $\left.\mathrm{SO}_{4}\right)$ determination. $\mathrm{pH}$ was measured by an electronic device calibrated in situ us- ing buffer solutions. In the laboratory, chemical analyses of the major constituents were carried out by ion chromatography (Dionex ICS-1100) on both filtered $(0.45 \mathrm{~mm})$ acidified $\left(\mathrm{HNO}_{3}\right.$ Suprapur) water samples $(\mathrm{Na}, \mathrm{K}, \mathrm{Mg}$, and $\mathrm{Ca}$ ), and untreated samples $\left(\mathrm{F}, \mathrm{Cl}, \mathrm{Br}, \mathrm{NO}_{3}\right.$, and $\left.\mathrm{SO}_{4}\right)$. The $\mathrm{HCO}_{3}$ 
Table 2. Dissolved gas composition and helium isotopic ratio of the seawater from the studied localities in the Ionian Sea (GeoC1, 2, and 3, and BMV). Data for the fluids sampled in a well adjacent to the Palizzi mud volcano (PMV) on the Calabria mainland are also reported. BDL: below detection limit, na: not analyzed.

\begin{tabular}{|c|c|c|c|c|c|c|c|c|}
\hline Site & Depth (m) & $\mathrm{He}\left(\mathrm{cc} \mathrm{L}^{-1}\right)$ & $\mathrm{O}_{2}\left(\mathrm{cc} \mathrm{L}^{-1}\right)$ & $\mathrm{N}_{2}\left(\mathrm{cc} \mathrm{L}^{-1}\right)$ & $\mathrm{CH}_{4}\left(\mathrm{cc} \mathrm{L}^{-1}\right)$ & $\mathrm{CO}_{2}\left(\mathrm{cc} \mathrm{L}^{-1}\right)$ & $\mathrm{R} / \mathrm{Ra}$ & $\mathrm{He} / \mathrm{Ne}$ \\
\hline \multirow[t]{8}{*}{$\mathrm{GeoC} 1$} & 1000 & 7.14E-05 & 3.95 & 9.31 & $1.37 \mathrm{E}-04$ & $5.28 \mathrm{E}-01$ & 0.94 & 0.30 \\
\hline & 900 & $6.11 \mathrm{E}-05$ & 3.97 & 9.64 & $7.62 \mathrm{E}-05$ & $5.10 \mathrm{E}-01$ & 1.07 & 0.27 \\
\hline & 800 & 7.74E-05 & 3.75 & 8.85 & $7.23 \mathrm{E}-05$ & 4.73E-01 & 0.94 & 0.27 \\
\hline & 700 & $6.86 \mathrm{E}-05$ & 3.95 & 9.30 & $9.14 \mathrm{E}-05$ & $4.80 \mathrm{E}-01$ & 1.01 & 0.24 \\
\hline & 500 & $5.51 \mathrm{E}-05$ & 4.16 & 9.45 & $6.86 \mathrm{E}-05$ & 4.73E-01 & 0.93 & 0.27 \\
\hline & 300 & $5.56 \mathrm{E}-05$ & 4.10 & 9.40 & $8.38 \mathrm{E}-05$ & $4.95 \mathrm{E}-01$ & 1.00 & 0.24 \\
\hline & 200 & $6.35 \mathrm{E}-05$ & 4.58 & 9.73 & $5.61 \mathrm{E}-05$ & $5.04 \mathrm{E}-01$ & 0.88 & 0.27 \\
\hline & 100 & $6.61 \mathrm{E}-05$ & 4.41 & 8.90 & BDL & 4.75E-01 & 0.93 & 0.30 \\
\hline \multirow[t]{9}{*}{ GeoC2 } & 1649 & $6.01 \mathrm{E}-05$ & 3.93 & 9.35 & $2.07 \mathrm{E}-04$ & $5.64 \mathrm{E}-01$ & 0.77 & 0.28 \\
\hline & 1500 & $5.84 \mathrm{E}-05$ & 4.23 & 8.98 & $1.07 \mathrm{E}-04$ & 5.37E-01 & 0.92 & 0.26 \\
\hline & 1300 & na & 3.77 & 8.98 & $1.24 \mathrm{E}-04$ & $4.62 \mathrm{E}-01$ & na & na \\
\hline & 1000 & na & 4.24 & 9.62 & $2.30 \mathrm{E}-05$ & $4.56 \mathrm{E}-01$ & na & na \\
\hline & 700 & na & 4.04 & 9.99 & $1.77 \mathrm{E}-04$ & 4.67E-01 & na & na \\
\hline & 600 & na & 3.94 & 9.21 & $6.90 \mathrm{E}-05$ & 4.39E-01 & na & na \\
\hline & 500 & na & 3.79 & 8.79 & $5.82 \mathrm{E}-05$ & $4.50 \mathrm{E}-01$ & na & na \\
\hline & 300 & na & 4.24 & 9.48 & 7.67E-05 & $4.67 \mathrm{E}-01$ & na & na \\
\hline & 100 & na & 4.38 & 9.10 & $1.07 \mathrm{E}-04$ & $4.54 \mathrm{E}-01$ & na & na \\
\hline \multirow[t]{5}{*}{ GeoC3 } & 2029 & 8.73E-05 & 3.98 & 9.20 & 5.33E-05 & $4.54 \mathrm{E}-01$ & 0.766 & 0.422 \\
\hline & 1500 & $6.75 \mathrm{E}-05$ & 3.51 & 9.85 & $1.90 \mathrm{E}-04$ & 4.97E-01 & 0.950 & 0.290 \\
\hline & 1000 & 7.17E-05 & 3.99 & 9.34 & $4.57 \mathrm{E}-05$ & 4.74E-01 & 0.927 & 0.366 \\
\hline & 500 & 7.13E-05 & 3.61 & 9.33 & $2.02 \mathrm{E}-04$ & $4.90 \mathrm{E}-01$ & 0.976 & 0.289 \\
\hline & 100 & na & 4.54 & 9.30 & $9.14 \mathrm{E}-05$ & $4.68 \mathrm{E}-01$ & na & na \\
\hline \multirow[t]{9}{*}{ BMV } & 1337 & 8.27E-05 & 3.99 & 9.12 & $2.51 \mathrm{E}-03$ & $7.31 \mathrm{E}-01$ & 0.73 & 0.398 \\
\hline & 1200 & na & 3.94 & 9.33 & $1.22 \mathrm{E}-04$ & $5.67 \mathrm{E}-01$ & nd & na \\
\hline & 1000 & 7.70E-05 & 4.08 & 9.90 & $1.45 \mathrm{E}-04$ & $5.03 \mathrm{E}-01$ & 0.92 & 0.256 \\
\hline & 800 & na & 3.97 & 9.37 & $9.90 \mathrm{E}-05$ & $5.22 \mathrm{E}-01$ & na & na \\
\hline & 700 & na & 3.76 & 8.88 & $1.07 \mathrm{E}-04$ & $4.85 \mathrm{E}-01$ & na & na \\
\hline & 500 & na & 3.87 & 8.60 & $1.45 \mathrm{E}-04$ & $4.23 \mathrm{E}-01$ & na & na \\
\hline & 300 & na & 3.97 & 9.75 & $1.35 \mathrm{E}-04$ & $5.50 \mathrm{E}-01$ & na & na \\
\hline & 200 & na & 4.61 & 9.58 & $1.52 \mathrm{E}-04$ & $4.59 \mathrm{E}-01$ & na & na \\
\hline & 100 & na & 6.47 & 1.59 & $1.29 \mathrm{E}-04$ & 4.80E-01 & na & na \\
\hline PMV & on land & 2.62E-03 & BDL & 22.28 & $6.87 \mathrm{E}+00$ & $1.23 \mathrm{E}-01$ & $1.60 \mathrm{E}-01$ & 17 \\
\hline ASSW & & $4.80 \mathrm{E}-05$ & 4.80 & 9.60 & $1.00 \mathrm{E}-06$ & $2.40 \mathrm{E}-01$ & 1 & 0.267 \\
\hline
\end{tabular}

content was measured by standard titration procedures with hydrochloric acid. Typical uncertainties are $\pm 5 \%$.

A few years ago (2003), one of us (Francesco Italiano) collected and analyzed fluid samples from a shallow well located on the Calabria mainland near the Palizzi mud volcano (PMV in Figs. 1 and 2, located about $25 \mathrm{~km}$ to the WNW of the BMV area). Unfortunately, no documentation exists concerning the PMV except our original geochemical data reported in Tables 1 and 2. The PMV was indeed actively venting geofluids at the time of our sampling (2003), but it was then soon destroyed by human activity and cementation.

\section{Results}

\subsection{Earthquakes}

The number of earthquakes recorded in the BMV area (i.e., the area shown in Fig. 2a) between 1985 and 2017 at depths $\leq 40 \mathrm{~km}$ is $178\left(M_{\mathrm{w}} \leq 4.5\right.$; Table $\left.\mathrm{S} 1\right)$. Focal mechanisms are from earthquakes that are $\leq 4.5$ in magnitude and $\leq$ $30 \mathrm{~km}$ in depth (Table S2). During the considered time window, no larger-magnitude earthquakes ( $>M_{\mathrm{w}} 4.5$ ) occurred. These mechanisms are mostly characterized by strike-slip and transtensional faulting along NW-SE-striking planes or along the conjugate planes striking NE-SW. 
Figure $2 \mathrm{~b}$ shows a transect-perpendicular projection (swath profile) of the above-described earthquake data (i.e., hypocenters and focal mechanisms; Tables S1 and S2) along a NE-SW vertical transect through the BMV (see the A-A' transect track in Fig. 2a). Projected seismic events were selected within an arbitrary distance (swath width) of $12 \mathrm{~km}$ from the transect track (Fig. 2a). Earthquake hypocenters are diffuse over the studied transect including the area beneath the BMV (Fig. 2b). A cluster of hypocenters is discernible near the northeastern tip of the transect (Fig. 2b). This same cluster is also visible as a NW-trending cluster of epicenters in the northeastern portion of the study area (i.e., $40 \mathrm{~km}$ to the northeast of the BMV; Fig. 2a).

\subsection{Bathymetry and geomorphology}

The study area is located on the upper part of the continental slope of the Calabrian-Ionian margin (Figs. 1 and S1) between 120 and $2000 \mathrm{~m}$ of water depth. This area is characterized by a complex morphology due to the interaction between tectonically controlled escarpments and several smallscale mass-wasting features, including slide scars (Ss), regional scarps (Rs), and gullies (G) or channels (Ch) (Fig. 3). The upper part of the continental slope is characterized by a very steep slope (about $15^{\circ}$ in average dip) that can reach, in places, a maximum dip of $28^{\circ}$ along the main escarpments oriented NE-SW and up to $35 \mathrm{~km}$ (Fig. 3b). At the foot of the upper continental slope, a well-defined flat area of about $26 \mathrm{~km}^{2}$ occurs, encompassing the subcircular morphological high of the BMV (Fig. 3). The flat area is located at $1350 \mathrm{~m}$ of water depth and bordered by several small ridges that are elongated parallel to the continental slope. The BMV is characterized by a circular shape with a diameter of about $1100 \mathrm{~m}$ and a well-defined rim (Figs. 3 and 4). The BMV has an elevation of about $22 \mathrm{~m}$ from its base (i.e., the surrounding plain) and steep slopes (see the slope profile in Fig. 4a). The high-resolution digital elevation model shows some complex structural and morphological features (Fig. 4). These features consist of concentric morphologies, each with its perimetric topographic rim. The concentric morphologies are separated by some moats and encompassed by the outermost topographic rim of the BMV (Fig. 4). Furthermore, on top of the BMV, three minor subcircular-arcuate bulges are present. These features have a relief of about $3 \mathrm{~m}$ with respect to the surrounding seafloor and are separated by small subcircular moats (Fig. 4b). The outermost topographic rim of the BMV is interrupted in the southern side (Fig. 4b). Multibeam backscatter data indicate low-amplitude acoustic signals, whereas the absence of changes or anomalies in the amplitude indicates a clayey-pelitic sedimentary cover (Fig. 5a).

To better understand the morphology of the BMV, also in comparison with other known mud volcanoes on the Earth, we consider recent compilations of mud volcano morphological data. We refer, in particular, to the works by Kirkham et al. (2017) and Kioka and Ashi (2015), in which relations between mud volcano height $H$ vs. diameter $D$ and volume $V\left(=\pi R^{2} H / 3\right)$ vs. $H / R$ ratio (where $R$ is the radius of the volcano base) are explored, respectively. Thus, the BMV volume $V=6.9 \times 10^{6} \mathrm{~m}^{3}$ is computed with the previous formula, after estimating its diameter and height through the use of high-resolution multibeam bathymetry data $(D=1100 \mathrm{~m}$ and $H=22 \mathrm{~m}$; Fig. 4). We used the same given formula to compute mud volcano volumes from the dataset provided by Kioka and Ashi (2015). However, some of these cataloged mud volcanoes are reported without diameter. Hence, we selected only the 232 mud volcanoes for which both the diameter $D$ and the height $H$ (Fig. 6a) are available. Figure 6 shows $H$ vs. $D$ (Fig. $6 \mathrm{~b}$ and c) and $V$ vs. $H / R$ (Fig. 6d) for the 632 selected mud volcanoes. When using the relation $V=\pi R^{2} H / 3$, volumes are calculated following the method proposed by Kioka and Ashi (2015), corresponding to the volume of the cone even though many volcanoes have a flattopped summit and may be better approximated to a trunk cone (e.g., potentially the BMV). Figure $6 \mathrm{~b}$ and $\mathrm{c}$ show that some mud volcanoes display a large diameter but low relief, whereas very few mud volcanoes exhibit a small diameter but prominent topography. An approximately linear trend between increasing diameters and heights can be inferred. In this trend, the BMV stands close to the low $D$ and $H$ values. Figure $6 \mathrm{~d}$ shows that the $H / R$ ratio of all mud volcanoes is $\leq 0.4$. The same ratio for the BMV is $<0.1$. There is a scattered distribution of volumes $(V)$, mostly ranging in the $10^{6}-10^{9} \mathrm{~m}^{3}$ interval. The BMV volume $\left(6.9 \times 10^{6} \mathrm{~m}^{3}\right)$ is highlighted in Fig. 6 d.

\subsection{Single-channel chirp seismic reflection profiles}

In the chirp seismic profiles (253, 241, and 246 in Fig. 7b-d), we recognized the following seismostratigraphic units.

Unit U0 corresponds to the seafloor seismic unit of the BMV and is characterized by sharp bottom echoes with no sub-bottom reflections or acoustic penetration with chaotic reflections and locally large hyperbolae. Adjacent to the BMV, we recognized the following four further seismic units (U1, U2, U3, and U4).

Unit $\mathrm{U} 1$ is mostly characterized by parallel to subparallel semicontinuous reflections with variable amplitude. The upper boundary is defined by a horizon (H1) generally characterized by a reflector with high amplitude and high continuity. Locally (e.g., toward the BMV), the amplitude and continuity of horizon $\mathrm{H} 1$ decrease and its reflection becomes indistinguishable. Furthermore, the H1 reflector is locally erosive in the sector adjacent to the BMV and tends to become a conformity surface far away from the BMV. Locally, toward the northern escarpment, reflections in $\mathrm{U} 1$ are truncated by an erosional surface. Adjacent to the BMV, normal faults displaced this unit.

Unit U2 is characterized by a quasi-transparent (reflectionfree) seismic facies and shows draping of the underlying re- 

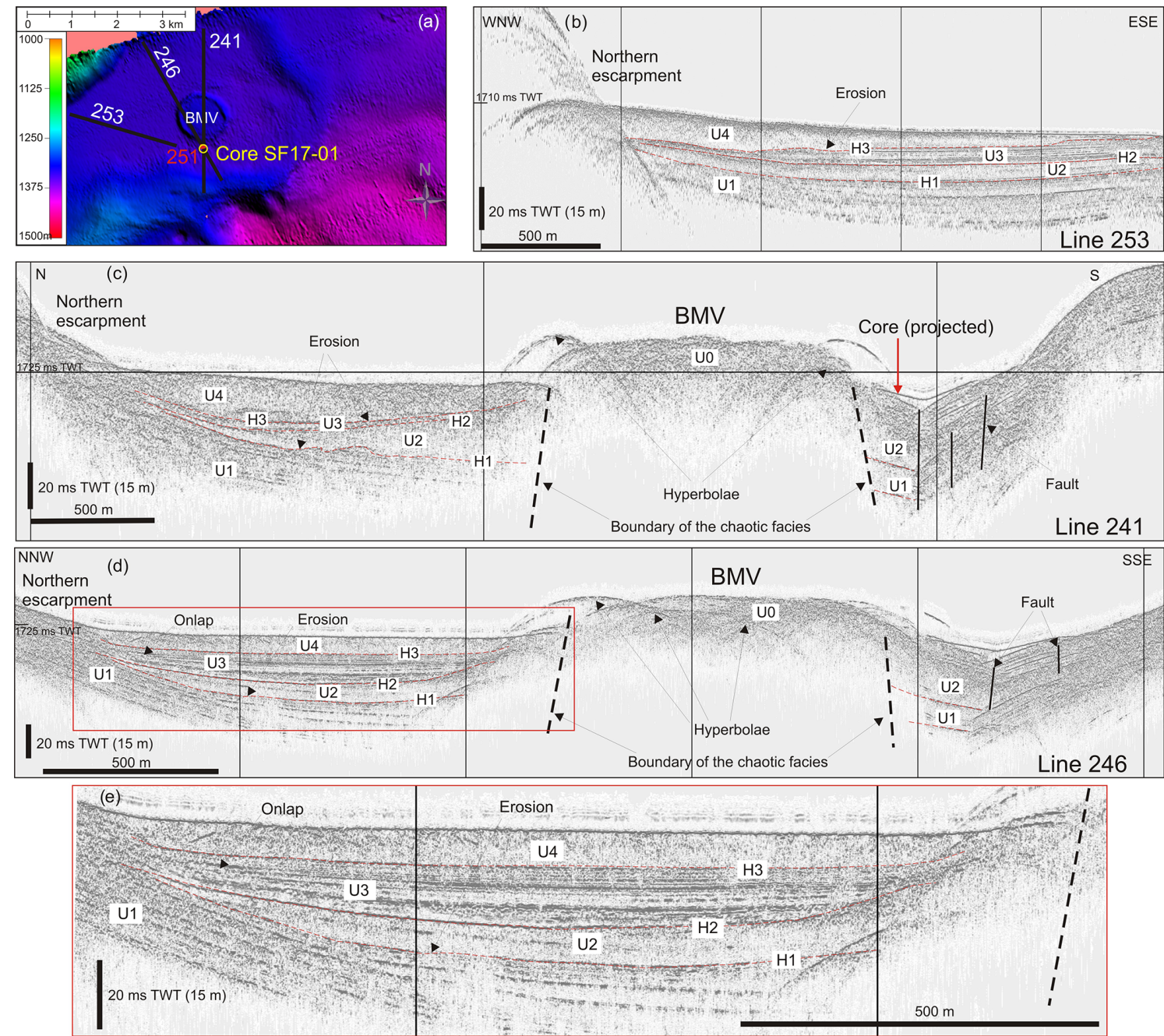

Figure 7. (a) Location map of three single-channel chirp profiles and one gravity core in the BMV area. The red dot (numbered 251) below the location of the gravity core indicates the location of the single-channel chirp profile 251 shown in Fig. 9. (b) Line 253. (c) Line 241. (d) Line 246. (e) Enlargement of Line 246 (see the red rectangle in Fig. 7d). Chirp profiles show main seismic units (U0-U4) and bounding horizons identified in the shallow subsurface. The high-resolution non-interpreted version of this figure is available in the Supplement (Fig. S1).

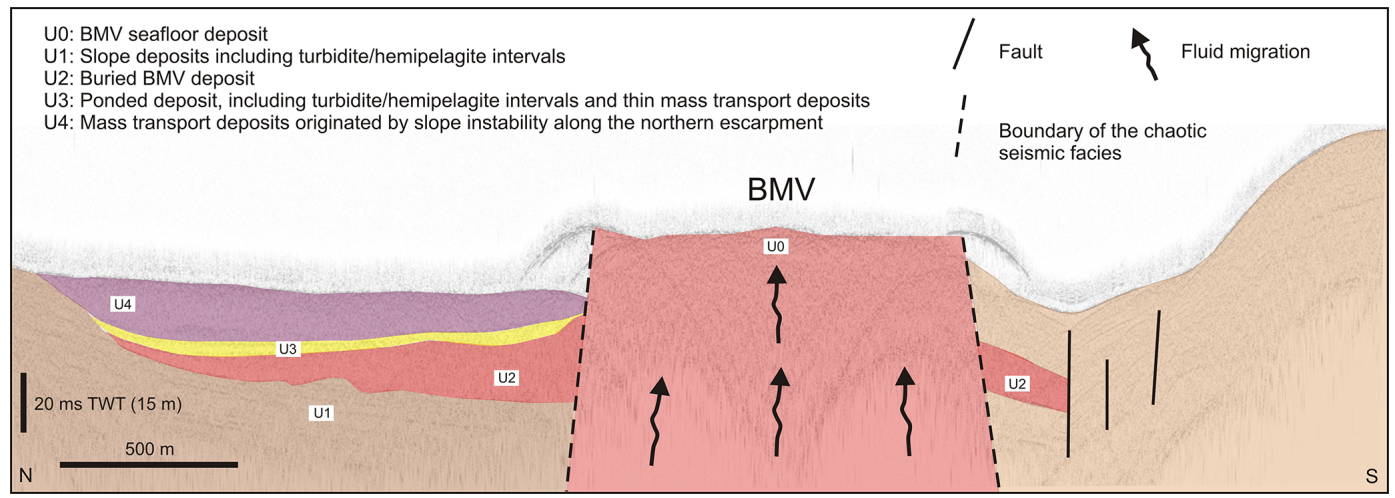

Figure 8. Interpretation of the chirp profile 241 shown in Fig. 7 (see text for details). 
lief. This unit has a wedge-shaped morphology thickening toward the flank of the BMV (241 in Fig. 7c), where it reaches a thickness of at least $25 \mathrm{~ms}$. The lower boundary of U2 is the horizon $\mathrm{H} 1$, whereas the upper boundary is defined by a horizon (H2) characterized by a reflector with high to medium amplitude and high continuity that locally (e.g., toward the $\mathrm{BMV}$ ) become discontinuous. Horizon $\mathrm{H} 2$ is an erosional surface with local extent. U2 is distributed in the sector between the northern escarpment and the BMV and is confined by the northern escarpment. Locally, U2 can also be recognized along the southern flank of the BMV edifice (246 in Fig. 7d).

Unit U3 is characterized by high-amplitude reflections and limited thickness. The internal filling configuration of this unit is a parallel onlap. Locally, the seismic facies is semitransparent. The lower boundary of U3 is represented by horizon $\mathrm{H} 2$, whereas the upper boundary is defined by a horizon (H3) characterized by a reflector with high to medium amplitude and high continuity. In places, the amplitude and continuity of horizon H3 decrease. Furthermore, horizon H3 is locally characterized by erosion.

Unit U4 is characterized by a transparent or chaotic seismic facies $(241,246$, and 253 in Fig. 7b-d). It has a wedgeshaped morphology and thickening toward the northern escarpment (max. thickness of about $20 \mathrm{~ms}$ ). The lower boundary of U4 is represented by horizon $\mathrm{H} 3$, locally characterized by erosion. The upper boundary is the seafloor. U4 is clearly discernible (max. thickness ca. $20 \mathrm{~ms}$ TWT) in the sector between the northern escarpment and the BMV and less discernible but still present (max. thickness ca. $4 \mathrm{~ms}$ TWT) to the south of the BMV.

\subsection{Sea-bottom gravity core}

We collected the SF17-01 core at the toe of the peripheral rim marking the external slopes of the BMV (Fig. 7a). Chirp profiles collected during coring operations (Figs. 7b-d and 8) show a chaotic unit (U4, Figs. 7b-d and 8) resting on the mud volcano. Chirp-core correlation suggests that the chaotic and transparent sediments are represented by the $2 \mathrm{~m}$ thick finingupward resedimented unit between 0.50 and $2.50 \mathrm{~m}$ of depth (Fig. 9). The base of this unit is marked by an abrupt increase in sand content and by an erosional basal contact (Fig. 9).

Although the gravity core did not sample mud breccias, it shows indirect evidence of fluid flow and mudflow as pointed out by the presence of patchy-cloudy facies (sensu Staffini et al., 1993; Cita et al., 1996) for which sediment disturbance is caused by fluid expulsion. According to Staffini et al. (1993), the main feature of a patchy-cloudy facies is that the mud breccia is characterized by patches and clouds of different colors. No visible clasts larger than sand size are observed and the mud breccia shows typical color changes. The sampled section below the base of the resedimented unit is characterized by silty-clay bulk sediments containing irregularly clustered intervals of differently colored sediment patches (from dark grey, olive grey, and brownish clouds within a grey matrix) with several fragmented and vertically dislocated thin silty turbidites and volcanoclastic layers (Fig. 9). Sediments contain several vertical or subvertical micro-pipes. The presence of the patchy-cloudy facies in the core is identified by changes in magnetic susceptibility, whereas the sand content does not show diagnostic changes (Fig. 9).

\subsection{Multichannel seismic reflection profiles}

The CROP M-31 and CA99-215 profiles (Fig. 10) are located within the inner plateau of the Calabrian Arc, a morphologically flat area with forearc basins formed on the top of the continental basement (Polonia et al., 2011, 2016). The inner plateau of the Calabrian Arc is characterized by a generally thick portion of Plio-Quaternary deposits overlying the Messinian sediments sampled in several nearby boreholes (e.g., Floriana 1 and Fosca 1 wells; Figs. 1 and 10f) and recognized in both the CROP M-31 and CA99-215 seismic profiles (Polonia et al., 2016). Below the Messinian deposits, the upper Oligocene-upper Miocene turbidite deposits unconformably overlie the basement units.

The seismic profiles are characterized by different structural domains with peculiar deformation patterns (Polonia et al., 2016). In particular, the Ionian Fault system (see this system in map view in Fig. 1) is observed in the seismic profiles (between s.p. 200 and 1400 of the A99215 profile; Fig. 10b). The Ionian Fault system, characterized by transtensive faulting, seems to reactivate preexisting Miocene-Pliocene thrusts (Polonia et al., 2016) and separates the Calabrian Arc into two sectors: the western and the eastern lobes (Figs. 1 and 10). The eastern lobe, where the BMV is located, is characterized by a more elevated accretionary wedge and by steeper topographic slopes than those of the western lobe, as shown in the sector between s.p. 1500 and 2600 of the CA99-215 profile (Fig. 10; Polonia et al., 2011).

\subsection{Geochemical features of four seawater columns}

The analytical results in terms of the chemical and isotopic composition of the water samples and the dissolved gases are listed in Tables 1 and 2, respectively. The fault zone data $(\mathrm{GeoC} 1,2$, and 3) are from samples coming from vertical casts performed far from the BMV over the Ionian and Alfeo-Etna fault systems (Fig. 1). The typical composition of air-saturated seawater (ASSW) is reported for comparison (Tables 1 and 2).

The five seawater samples collected along the water column over the BMV (except the sample collected near the seabed) show a chemical composition similar to the fault zone samples (GeoC1, 2, and 3; Fig. 11 and Tables 1 and 2). The concentration values for major cations $(\mathrm{Na}, \mathrm{K}, \mathrm{Mg}, \mathrm{Ca}$; Table 1) show similar values for the GeoC1, 2, and 3 sam- 

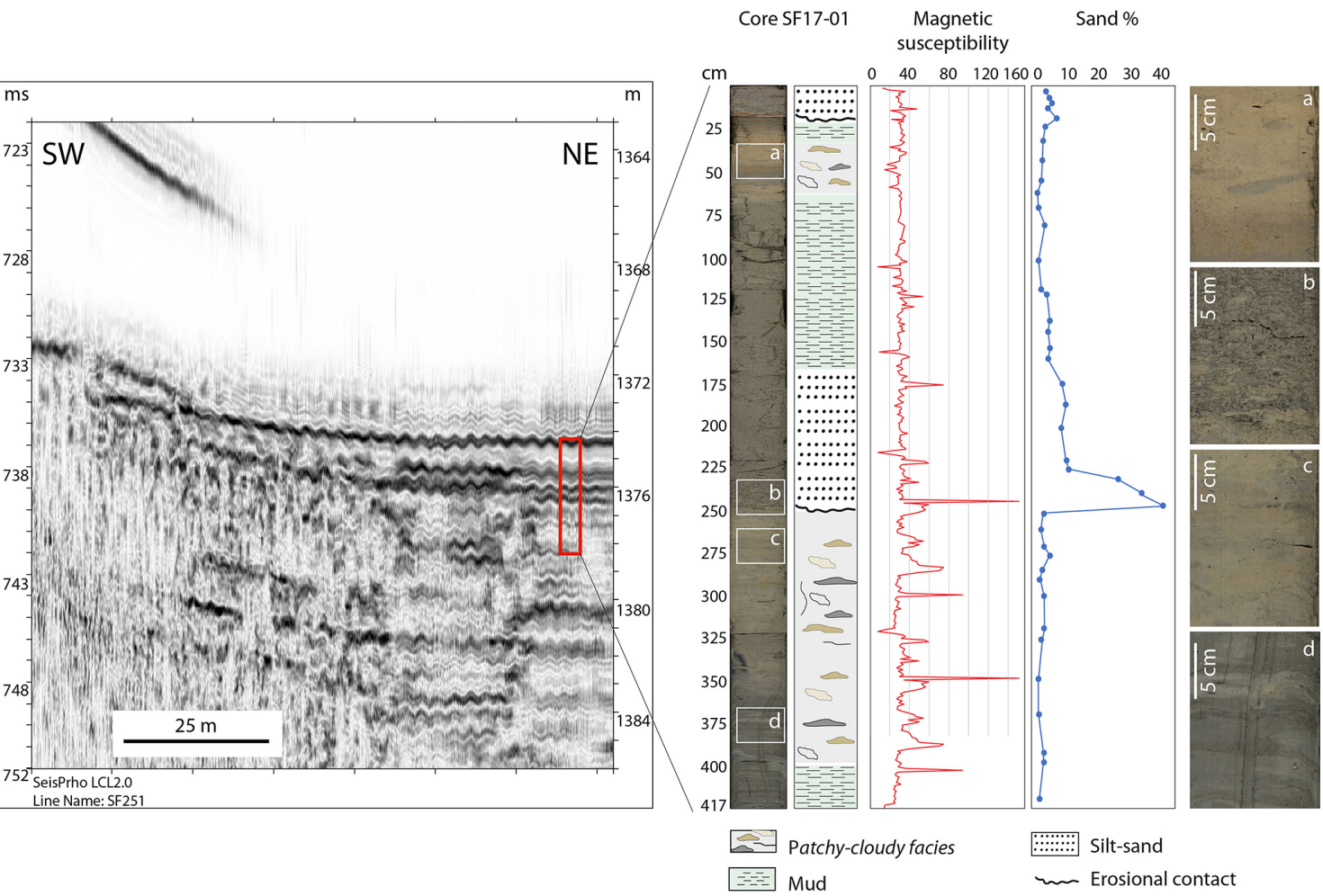

Figure 9. Correlations between the 251 chirp profile (left) and the SF17-01 gravity core (right). See locations in Fig. 7 . Left: 251 chirp profile collected during coring operations. Right: photograph, lithological log, high-resolution magnetic susceptibility, and sand content of the SF17-01 gravity core. Magnetic susceptibility is rather constant throughout the core with the exception of some peaks in the lower part of the core, where the patchy-cloudy facies (sensu Staffini et al., 1993) is present. A peak in magnetic susceptibility marks the abrupt increase in sand content at the base of the resedimented deposit between 75 and $250 \mathrm{~cm}$. Labels a, b, c, and d represent close-ups of different core units: $a, c$, and $d$ are patchy-cloudy facies, whereas $b$ is the base of the resedimented unit.

ples and the ones from the BMV (including water column and bottom samples). The dissolved gases detected along the water column (Table 2) exhibit geochemical features with large differences from the seawater equilibrated with the atmosphere (ASSW). In particular, the composition of the dissolved gases (Table 2) shows the presence of air-derived gases $\left(\mathrm{N}_{2}\right.$ and $\left.\mathrm{O}_{2}\right)$ along with non-atmospheric gases $\left(\mathrm{CO}_{2}\right.$ and $\mathrm{CH}_{4}$ ). The analytical results clearly display a slight decrease in oxygen content (i.e., compare ASSW and the rest of the data in Fig. 11) besides a significant increase in $\mathrm{He}, \mathrm{CH}_{4}$, and $\mathrm{CO}_{2}$. The $\mathrm{CH}_{4}$ content along the water column and at the sea bottom (BMV and $\mathrm{GeoC} 1,2$, and 3 ) ranges over 2 to 3 orders of magnitude higher than the ASSW, with the highest concentration recorded at the BMV depth $(-1337 \mathrm{~m})$. The $\mathrm{CO}_{2}$ content above the BMV, in particular, is double the ASSW (0.24 ccSTP L $\left.{ }^{-1}\right)$ at the depth of $100 \mathrm{~m}$ and increases up to $0.73 \mathrm{ccSTPL}^{-1}$ at the sea bottom $(-1337 \mathrm{~m})$ (Fig. 11 and Table 1).

The PMV is characterized by a dissolved gas phase mainly composed of nitrogen and $\mathrm{CH}_{4}$, with a significant helium concentration and a slight amount of $\mathrm{CO}_{2}$. Oxygen is below the detection limit (Tables 1 and 2).
The helium isotopic signature of samples coming from the $\mathrm{GeoC} 1,2$, and 3 casts show an atmospheric signature from the surface to the depth of $1000 \mathrm{~m}$. The bottom sample displays a lower ratio than the air with a higher ${ }^{4} \mathrm{He} /{ }^{20} \mathrm{Ne}$ ratio. Two samples from the BMV cast were analyzed to determine the helium isotopes. Results approximately match those from the GeoC1, 2, and 3 casts, showing a slight but detectable difference with respect to the atmospheric ratios (as expected for an ASSW) for both ${ }^{3} \mathrm{He} /{ }^{4} \mathrm{He}$ and ${ }^{4} \mathrm{He} /{ }^{20} \mathrm{Ne}$ (Fig. 11 and Tables 1 and 2).

\section{Interpretation}

In this section, we interpret some of the presented data, particularly (but not only) the seismic ones (Figs. 7-10) that require specific interpretation. Further discussion on and synthesis of all data are reported in the next section.

First of all, earthquake epicenters and focal mechanisms (Figs. 1 and 2) show that the area surrounding the BMV is seismically active as it is populated by earthquakes. Concerning the activity of the BMV, consistent with the resolution of the multibeam equipment, multibeam water column data 

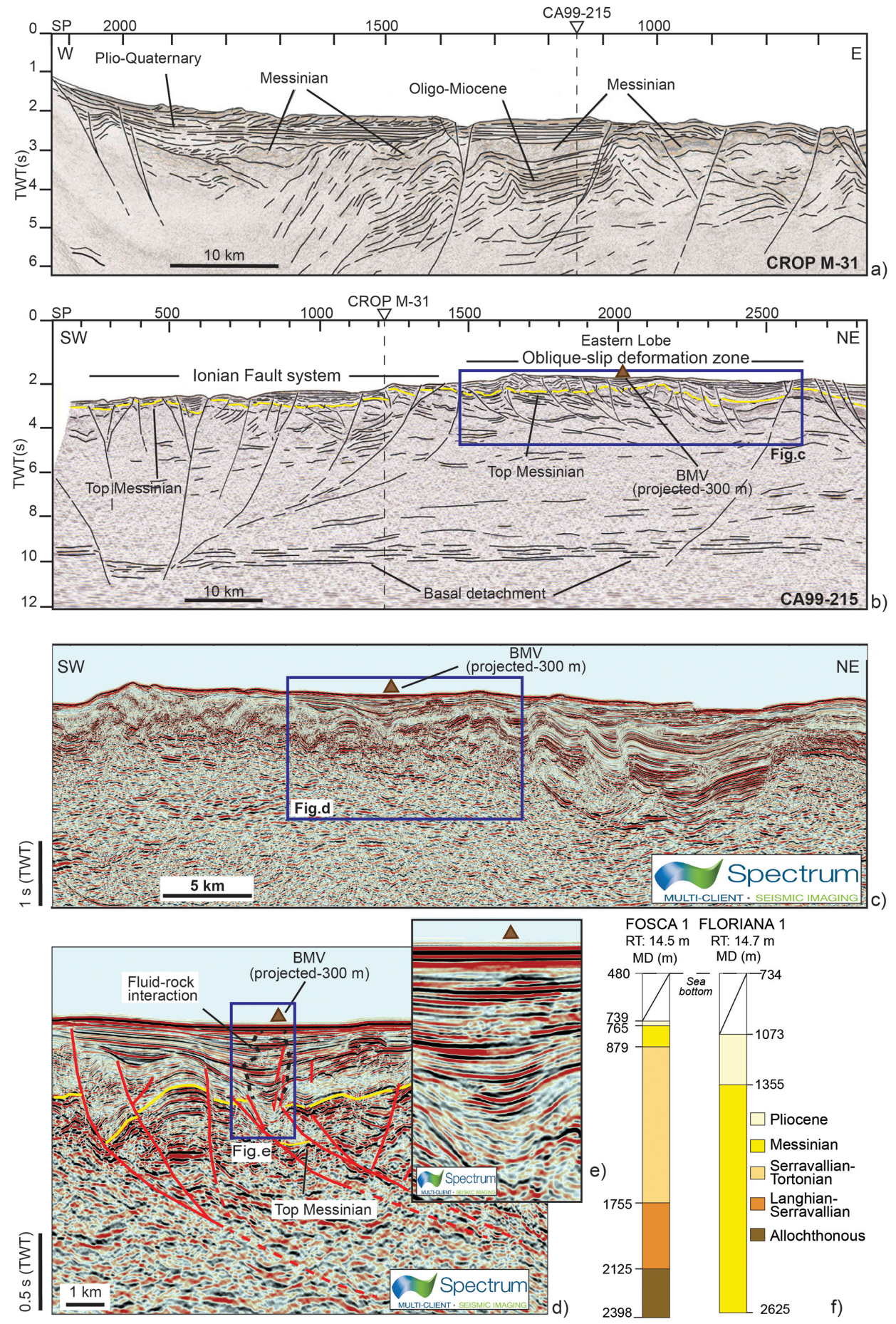

Figure 10. (a) CROP M-31 seismic reflection profile (track in Fig. 1) in the version interpreted by Polonia et al. (2016), showing the complex structural setting and the main interpreted deposits. The CROP M-31 profile crosses the CA99-215 profile at shot point (s.p.) 1150. (b) CA99215 seismic reflection profile (track in Fig. 1) in the version interpreted by Polonia et al. (2016). The top of the Messinian deposits is reported in yellow. The CA99-215 profile crosses the CROP M-31 profile at s.p. 1210. (c) Portion of the CA99-215 profile reprocessed by Spectrum Geo Ltd (https://www.spectrumgeo.com/, last access: 15 May 2019). The BMV is projected from a distance of $\simeq 300 \mathrm{~m}$. (d, e) Close-up views of a portion of the reprocessed CA99-215 profile where the BMV is located. See Fig. S3 for a non-interpreted high-resolution version of Fig. 10e. Note that the Messinian and Pliocene deposits are faulted by normal and thrust faults. The area just below the projection of the BMV is characterized by a chaotic seismic reflection pattern for the fluid-rock interaction similar to many other mud volcanoes. (f) Stratigraphic syntheses of the Fosca 1 and Floriana 1 wells (see location in Fig. 1). RT: rotary table. MD: measure depth. Raw well data are from the Videpi free database (available only at https://unmig.sviluppoeconomico.gov.it/videpi/videpi.asp, last access: 15 May 2019). 


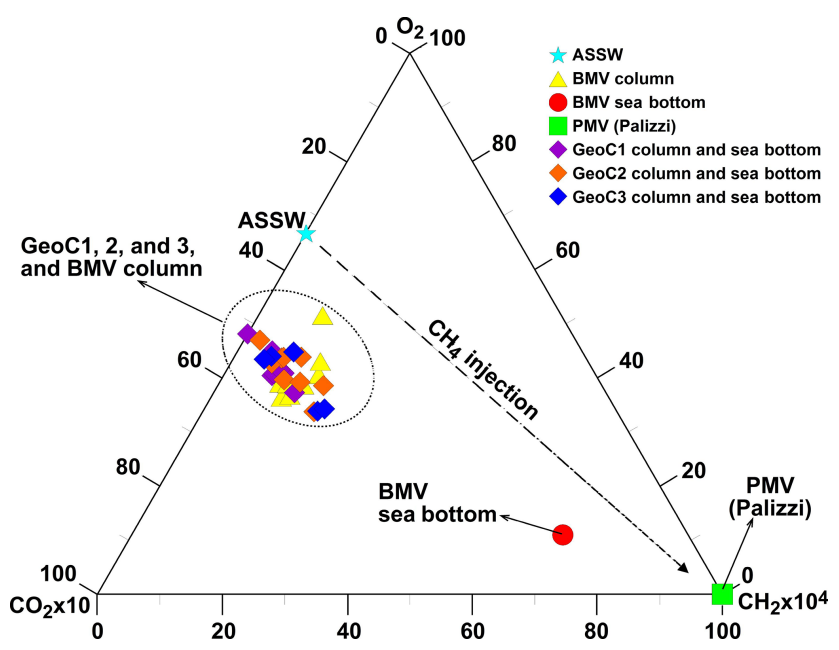

Figure 11. $\mathrm{CH}_{4}-\mathrm{O}_{2}-\mathrm{CO}_{2}$ diagram. The ternary plot shows the relative distribution of dissolved gases for the collected samples. Dissolved gas compositions coming from the sampling site above the BMV are compared with the local air-saturated seawater (ASSW). The figure shows typical endogenic components $\left(\mathrm{CO}_{2}\right.$ and $\left.\mathrm{CH}_{4}\right)$ versus the atmospheric component (represented here by $\mathrm{O}_{2}$ ).

recorded during the Seismofaults 2017 survey do not highlight acoustic backscatter anomalies related to large amount of fluids and mud escaped from the seafloor (Fig. 5b; e.g., Römer et al., 2014). This evidence suggests that no paroxysmal activity is ongoing (at least at the time of the Seismofaults 2017 survey) from the BMV. However, our geochemical data (Fig. 11) show active fluid circulation through the BMV. Further discussion on this theme is presented in the next section. Moreover, sediments from the gravity core contain several vertical or subvertical micro-pipes, suggesting sediment reworking by fluid migration (Fig. 9). We associate this sediment structure with the patchy-cloudy facies (e.g., Staffini et al., 1993; Cita et al., 1996), which was already described in the surrounding areas in association with geofluid ascent and mud volcanism (Panieri et al., 2013).

Concerning the single-channel chirp profiles, based on their seismic characteristics, we interpret the five seismic units identified in Fig. 7 as follows (Fig. 8).

Unit U0 is interpreted as the BMV main edifice. The transition between the rim and the summit caldera is identified by the large hyperbolae. The floor of the summit caldera is not penetrated by the seismic signal, possibly indicating the occurrence of mud breccia deposits that are typical of mud volcanoes (van der Meer, 1996; Gennari et al., 2013).

Unit U1 is interpreted as slope deposits including turbidite-hemipelagite intervals. Locally, slope deposits are eroded by U2 (i.e., mud volcano deposits).

Unit U2 is interpreted as a mud volcano deposit belonging to the BMV due to its wedge-shaped quasi-transparent (reflection-free) seismic facies thinning away from the BMV center. This deposit can be related to eruptive events or posteruptive instability of the following types.

1. Buried mudflow deposits. These are gravity flow deposits related to the slope instability of the mud volcano.

2. Buried mud volcano sediment. Similar wedge-shaped seismic units have been interpreted by Evans et al. (2008) as massive and structureless sediment extruded from the volcano center.

Unit U3 is interpreted as ponded deposits, including turbidite-hemipelagite intervals and thin mass transport deposits. Locally, ponded deposits are eroded by U4 (i.e., mass transport deposits).

Unit U4 is interpreted as consisting of mass transport deposits originated by slope instability along the northern escarpment (i.e., toward the coast). This interpretation is based on the quasi-transparent (reflection-free) seismic facies of this unit and on its wedge shape with reduced thickness moving away from the northern escarpment. Interpretation of U4 is also based on direct evidence from the gravity core in Fig. 9.

Concerning the multichannel seismic reflection profiles, the CA99-215 profile displays numerous faults characterized by different kinematics related to the complex evolution of the area, namely thrust faults, which are the result of the post-Messinian shortening, and normal and strike-slip faults deriving from the extensional process acting in more recent times (from lower Pleistocene to present times) as shown by the faults reaching the sea bottom on the eastern side of the seismic profiles (Fig. 10). Earthquake focal mechanisms located in the study area (Figs. 1 and 2) show that faults are mostly characterized by strike-slip and transtensional kinematics defining a clear flower-like structure on the western side and an oblique-slip deformation zone on the eastern side (Fig. 10b). In this area, one of the main reflective horizons, usually discernible in most seismic profiles, is the top of the Messinian deposits. The Messinian deposits cored in the nearby wells (in particular in the Gulf of Squillace) consist of clay-dominated deposits with interbedded gypsum, anhydrite, and halite (Capozzi et al., 2012). The Floriana 1 well shows, for instance, a thick portion (more than $1300 \mathrm{~m}$ ) of the Gessoso-Solfifera Formation (consisting of crystalline gypsum, anhydrite, and clay layers), whereas in the Fosca 1 well the Messinian deposits are mostly formed by clay and silt for a total thickness of $110 \mathrm{~m}$ (Fig. 10f). The distribution and sedimentary pattern of the Messinian deposits indeed suggest that the basin was already articulated and tectonically controlled at the time of Messinian sedimentation (Capozzi et al., 2012). The occurrence of Messinian evaporites as well as clays and silts of the same age is very relevant for mud volcanism. Indeed, according to many studies on mud volcanoes in the Ionian Sea and in the adjacent Mediterranean Ridge (located off southern Peloponnesus and Crete), the disruption of the Messinian low-permeability layers concurred 
with or was the key process controlling the ascent of pressurized fluids entrapped below these sealing layers and the consequent outflow and mud volcanism (Capozzi et al., 2012).

The identification on seismic profiles of submarine mud volcanoes (i.e., their subsurface roots) can depend on and be limited by different factors, such as the complexity of the tectonic setting and/or the seismic characteristics of the hosting succession (Dimitrov, 2002; Bertoni et al., 2017). Identification of mud volcanoes located in complex tectonic settings, such as the accretionary complex of the present work, is not straightforward; however, as we will explain below, we were able to observe a few seismic features that could be interpreted as diagnostic of mud volcanism and fluid-rock interaction (e.g., Dimitrov, 2002). For instance, immediately beneath the seafloor, where a mud volcano is located, seismic reflectors are usually characterized by locally strong amplitudes. This seismic effect can be associated with fluid-rock interaction (Dimitrov, 2002). Furthermore, a chaotically disrupted seismic pattern and short seismic horizons are typical features related to the presence of a conduit and fluidrock interaction beneath many mud volcanoes. Concerning the BMV (Figs. 10d, e, and S2), we observed the following main features: (1) the presence of top Messinian deposit reflectors; (2) the disruption of these reflectors; (3) the presence of normal faults; and (4) the presence of an area of fluidrock interaction similar to many observed in seismic profiles below mud volcanoes (Capozzi et al., 2012; Dimitrov, 2002; Bertoni et al., 2017). In particular, the area just below the BMV, which is about $300 \mathrm{~m}$ away from the CA99-215 profile (Fig. 1), shows (at a time-depth of $2 \mathrm{~s}$ TWT) a rock volume characterized by a chaotic seismic reflection pattern, with disrupted and short reflections (Figs. 10d, e and S2). This chaotic pattern is located in sediments otherwise characterized by reflectors showing high continuity. It is relevant to note that this area is placed right at the top of a series of faults. The Messinian evaporites are located between 2 and $3 \mathrm{~s}$ TWT. Considering a seismic velocity of $1500 \mathrm{~m} \mathrm{~s}^{-1}$ for the seawater column and $2000 \mathrm{~m} \mathrm{~s}^{-1}$ for the post-Messinian column of sediments (Gallais et al., 2012), the Messinian evaporites should occur at about $-3000 \mathrm{~m}$.

\section{Discussion}

\subsection{Origin and activity}

\subsubsection{General context}

Concerning the origin of the BMV, we reconsider all the above-described data. First of all, we mention the fact that the Ionian Sea, where two active accretionary prisms occur and obliquely converge (i.e., the Calabrian Arc and the Mediterranean Ridge), is a region rich in active or recently active mud volcanoes (Cita, 1981; Camerlenghi et al., 1992; Capraro et al., 2006; Serpelloni et al., 2007; Praeg et al.,
2009; Billi et al., 2011). The BMV itself was previously signaled and hypothesized as a mud volcano by Gutscher et al. (2017) and Loher et al. (2018). The BMV occurs on top of the Calabrian accretionary wedge in a rather isolated location with several further mud volcanoes occurring a few kilometers or a few tens of kilometers toward the NE along the prism (Fig. 1; Loher et al., 2018).

\subsubsection{Morphology}

From a morphological point of view, the main geometric features of the BMV are those typical of most mud volcanoes (i.e., Kioka and Ashi, 2015), and all its measured parameters (height $H$, diameter $D$, and volume $V$; Fig. 6 ) are well within the range typical of marine mud volcanoes (Kioka and Ashi, 2015; Kirkham et al., 2017). From the morphological analysis, the BMV could be primarily interpreted as a pie-type mud volcano; however, looking at the slope values highlighted by the acquired multibeam data (Fig. 4), the $<5^{\circ}$ slope angle criterion proposed by Kopf (2002) is not satisfied, with the BMV slope values being $>10^{\circ}$ (Fig. 4).

The stratigraphic analyses realized through direct and indirect methods (Figs. 7-10) show the occurrence of lithological units consistent with the activity of a mud volcano, such as the U2 deposits in Figs. 7c and 8, the evidence of fluid flow and mudflow in the patchy-cloudy facies of the gravity core (Fig. 9), and the chaotic seismic reflection signal with disrupted and short reflections (typical of mud volcanoes for the host rock-geofluid interaction; e.g., Dimitrov, 2002; Capozzi et al., 2012) beneath the BMV (Fig. 10d). However, from the available data, we cannot infer any eruptive dynamics for the BMV due to the limited resolution of the seismic imaging and to the BMV location with respect to the seismic lines (ca. $300 \mathrm{~m}$ ). The dimensions of the conduit and paleoflows are not visible in the seismic profiles, for example the Christmas-tree structures described by Somoza et al. (2003). From previous literature (e.g., Kioka and Ashi, 2015), we can only infer that the BMV dimensions and its computed volume suggest a polygenetic behavior, so we argue that the main fluid conduit has possibly been utilized several times to increase the volume of the volcano itself.

\subsubsection{Sealing}

Particularly in the Mediterranean Sea, the origin of most mud volcanoes has been linked in a cause-effect relationship with the sealing action exerted by the Messinian evaporites, causing fluid entrapment underneath and consequent fluid overpressure (Camerlenghi et al., 1995; Chamot-Rooke et al., 2005; Camerlenghi and Pini, 2009; Capozzi et al., 2012; Ceramicola et al., 2014; Rovere et al., 2014; Bertoni and Cartwright, 2015). Also in the case of the BMV, the seismic cross sections show the presence (and disruption underneath the BMV) of the Messinian evaporites (Fig. 10), which therefore may have been decisive in building the necessary 
overpressure of fluids to consequently form the mud volcano itself (Bertoni and Cartwright, 2015; Al-Balushi et al., 2016). The disruption of the Messinian layers suggests that the conduit for the ascent of geofluids through the BMV is presently open. This hypothesis is also substantiated by the geochemical data (Fig. 11) discussed below.

\subsubsection{Ongoing activity}

We have very little evidence to discuss the ongoing activity of the BMV because we collected data from this structure only in a single campaign in May 2017. From a morphological point of view, the BMV seems well structured (Fig. 4) and therefore its main edifice-building paroxysmal activity may have substantially ceased. Moreover, the flanks of the main volcanic edifice seem partly covered by younger products (i.e., over its flanks; Figs. 7c-d and 8) deriving from nearby gravity instabilities (i.e., from the continental slope of the Calabrian-Ionian margin; Figs. 1 and S1). Also, the backscatter data show no extensive anomalies (in May 2017) related to a large amount of mud and fluids escaped from the seafloor (e.g., Römer et al., 2014); however, this evidence does not detract from the fact that the volcano may currently be quiescent and therefore may erupt in the future. To this end, both the geochemical and the reflection seismic evidence shows that some fluid activity below the BMV is probably ongoing. Figure 11, in particular, shows a trend of $\mathrm{CH}_{4}$ and $\mathrm{CO}_{2}$ enrichment for all the collected samples with respect to seawater simply equilibrated with the atmosphere (ASSW). Although $\mathrm{CO}_{2}$ and $\mathrm{CH}_{4}$ may derive from degradation processes of organic matter, the geochemical composition of the seawater at the BMV depth and the composition of the geofluids from the PMV (Palizzi) on land area clearly indicate a $\mathrm{CH}_{4}$ injection that is typical of most mud volcanoes. The isotopic composition of helium, although dominated by a typical atmospheric signature at the GeoC1, 2, and 3 localities and at the BMV locality, displays a detectable increase in radiogenic ${ }^{4} \mathrm{He}$ of typical crustal origin, with an associated decrease in the isotopic ratio of about $0.93-1$ to $0.77 \mathrm{Ra}$ detected in the GeoC1, 2, and 3 sea-bottom waters and 0.73 Ra in the BMV sea-bottom water (Tables 1 and 2). Hence, we propose that the BMV is actually infiltrated by open pathways as shown by the release of fluids into the surrounding seawater (Fig. 11 and Tables 1 and 2). Fluids are composed of a two-phase system: a $\mathrm{CH}_{4}$-dominated gas phase and hypersaline waters of evaporite type. The hypersaline waters are indeed probably generated by the dissolution of anciently buried evaporites (Messinian) and create dense anoxic brines, which are separated from the overlying oxygenated deep-seawater column due to differential densities. The chaotic seismic reflection signal, with disrupted and short reflections (typical of active mud volcanoes; e.g., Dimitrov, 2002; Capozzi et al., 2012), recorded beneath the BMV (Fig. 10) and the disruption of the Messinian evaporite layers support the above-proposed hypothesis of pathways open to geofluids down to the Messinian evaporite layers (ca. $3000 \mathrm{~m}$ of depth; Fig. 10). Also, the gravity core bears evidence of recent fluid circulation (Fig. 9). Moreover, some structures on top of the BMV (i.e., the rim and some small ridges; Fig. 4ab) are morphologically similar to structures related to extrusion activity of mud volcanoes (e.g., Evans et al., 2008) and are therefore probably connected with the eruptive processes. These structures are not substantially covered by young sediments, hence attesting to a recent but undetermined time for the eruptive process of the BMV.

\subsubsection{Draining processes}

In accretionary prisms, the causes (i.e., the engine) of mud volcanoes and related fluid activity are often found or hypothesized to be either the prism contraction and related fluid squeezing or the fault activity and related fluid ascent along fault damage zones. In other words, mud volcanoes can be caused by a contraction-related local dewatering or by a deeper crustal draining driven by the activity of normal and strike-slip faults (Gamberi and Rovere, 2010; Capozzi et al., 2012; Panieri et al., 2013; Ceramicola et al., 2014; Rovere et al., 2014). In the case of the BMV, we cannot unambiguously discriminate between these two main engines (prism contraction vs. fault activity). We hypothesize that both engines may concur or may have concurred to originate the BMV. Overall contraction is indeed slightly active in the Calabrian accretionary prism (Serpelloni et al., 2007; Billi et al., 2011; Faccenna et al., 2014; Polonia et al., 2016), as is fault activity, particularly along prism-across (NW-SE) strike- to oblique-slip faults (Polonia et al., 2016, 2017). It is also true, however, that the seismological and reflection seismic data show the occurrence of a seismically active flower-like system of faults right beneath the BMV (Figs. 2 and 10). This evidence leads us to think that (seismic) faulting more than the prism contraction process may have played a decisive role in the origin and feeding of the BMV, thus ultimately driving the ascent of geofluids from crustal depths. To this end, Polonia et al. (2017) have recently documented the prismacross strike-slip faults in the Ionian Sea region as active and even capable of exhuming or contributing to exhuming serpentinite domes from the lower plate of the Ionian subduction zone up to the upper plate and the Earth's surface.

\subsubsection{Synthesis}

Collectively, the data presented in this paper provide evidence for the fact that the studied structure (i.e., the BMV) is actually a mud volcano, through which fault-related crustal fluid activity and circulation are ongoing and beneath which (seismic) faulting is active. 


\subsection{Potential use of the BMV in the science of seismic precursors}

\subsubsection{Previous useful results}

Concerning the use of the BMV and similar structures in monitoring and mitigating natural hazards, we first refer the reader to a few recent studies on geochemical precursors of earthquakes. Transient hydrogeochemical anomalies are increasingly becoming commonly recorded before $M \geq 5.0$ earthquakes at distances between 20 and more than $200 \mathrm{~km}$ from the earthquake epicenters. To understand their relevance for earthquake forecasting, we briefly recall a few recent instances from Italy, Iceland, India, Japan, and Turkey. The 2016 Amatrice and Norcia earthquakes (central Italy), as well as the related sequence, involved significant pore pressure changes (starting about 1 week before the Amatrice earthquake; De Luca et al., 2018) and fluid movements both at deep and shallow crustal levels (Petitta et al., 2018; Tung and Masterlark, 2018); they were anticipated by hydrogeochemical anomalies recorded since April 2016 in springs from the central Apennines. In particular, increases in As, V, and $\mathrm{Fe}$ contents were recorded in groundwaters from springs monitored in the Sulmona area, about $70 \mathrm{~km}$ to the southeast of the epicentral area. Similar anomalies (i.e., As, V, and $\mathrm{Fe}$ ) were also recorded in groundwaters from the San Chiodo spring located within the epicentral area (Barberio et al., 2017; Boschetti et al., 2019). In 1995, 8 months before the $M_{\mathrm{w}} 7.2$ Kobe earthquake (Japan), the $\mathrm{Cl}$ and $\mathrm{SO}_{4}$ concentrations in groundwater started to significantly and anomalously increase (20-30 km from the epicenter). About $9 \mathrm{~d}$ before the earthquake, a peak in $\mathrm{Rn}$ concentration was also recorded (King et al., 1995). In 2002, anomalies in Cu, Zn, Mn, and $\mathrm{Cr}$ concentrations were recorded in groundwater 1,2,5, and 10 weeks, respectively, before the $M_{\mathrm{w}} 5.8$ earthquake in northern Iceland $(90 \mathrm{~km}$ from the epicenter; Claesson et al., 2004). In 2012, anomalous increases in $\mathrm{Ca}, \mathrm{Mg}, \mathrm{K}$, and $\mathrm{Cl}$ concentrations in groundwater, together with decreases in $\mathrm{Na}$ and $\mathrm{SO}_{4}$ concentrations, started at least 20 to $30 \mathrm{~d}$ before the $M_{\mathrm{w}} 7.1$ Van earthquake, Turkey $(20 \mathrm{~km}$ from the epicenter; Inan et al., 2012). In 2012, significant increases in $\mathrm{Na}, \mathrm{Si}$, and Ca concentrations were recorded in groundwater 4-6 months before two $M_{\mathrm{w}} \geq 5.5$ earthquakes in northern Iceland (70$80 \mathrm{~km}$ from the epicenter; Skelton et al., 2014, 2019). In 2004 and 2005, transient hydrogeochemical anomalies were detected in an aquifer located to north of the Shillong Plateau, Assam, India, before two $M_{\mathrm{w}} \geq 5.0$ earthquakes $(200 \mathrm{~km}$ from the epicenter). The $[\mathrm{Na}]+[\mathrm{K}] /[\mathrm{Si}],[\mathrm{Na}] /[\mathrm{K}]$, and $[\mathrm{Na}]+[\mathrm{K}] /[\mathrm{Ca}]$ ratios, as well as conductivity, alkalinity, and $\mathrm{Cl}$ concentrations, began increasing 3-5 weeks before the $M_{\mathrm{w}} 5.3$ earthquake, whereas the $\mathrm{Ba} / \mathrm{Sr}$ ratio began decreasing 3-6 d before the $M_{\mathrm{w}} 5.0$ earthquake (Skelton et al., 2008). In 2017, oxygen isotopic ratio anomalies of $+0.24 \%$ o relative to the local background were recorded in groundwater a few months before the $M_{\mathrm{w}} 6.6$ Tottori earthquake in

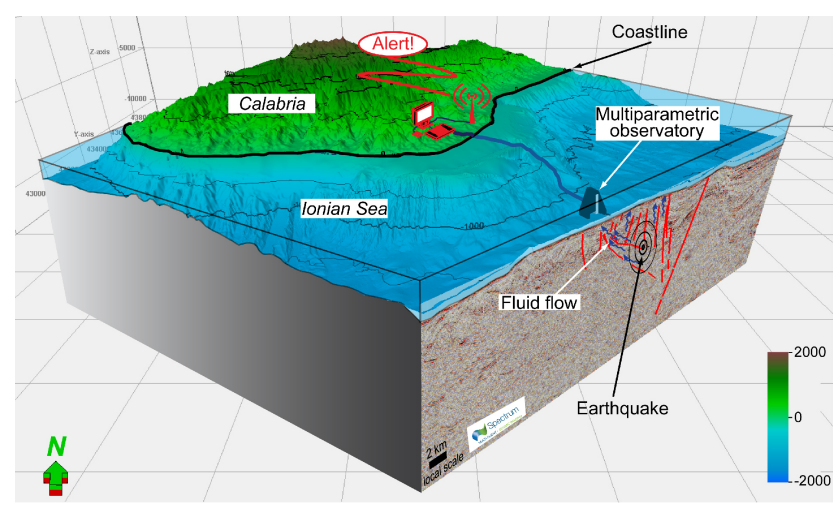

Figure 12. Conceptual scheme showing a future multiparametric cabled station on the BMV to geochemically track the seismic cycle of the underlying active faults and contribute to the mitigation of the seismic hazard.

southwest Japan (5 km from the epicenter; Onda et al., 2018). Although the aforementioned scientific results are certainly encouraging, we must acknowledge that earthquake deterministic forecasting is still unfeasible through both hydrogeochemical data and other evidence.

\subsubsection{The BMV}

The geochemistry of the seawater column (sampled in May 2017) above the BMV compared with the seawater benchmark (ASSW; Fig. 11) shows a clear mineralization of the BMV-related waters together with an injection of $\mathrm{CO}_{2}$ and $\mathrm{CH}_{4}$, particularly in proximity to the BMV depth (Fig. 11). Moreover, the helium isotope ratios (Table S4) show a contribution by crustal fluids, in this case particularly in proximity to the BMV depth. The ion content of the BMVrelated waters (Table 1) is consistent with evaporite-type waters and this notion, in turn, is consistent with the hypothesis that the fluids feeding the BMV and other mud volcanoes in the Mediterranean area are entrapped below and within the Messinian evaporites (Fig. 10d; Camerlenghi et al., 1995; Chamot-Rooke et al., 2005; Capozzi et al., 2012; Ceramicola et al., 2014; Rovere et al., 2014; Bertoni and Cartwright, 2015). Below the BMV, these rocks occur at about $-3000 \mathrm{~m}$ (Fig. 10d). The high $\mathrm{CO}_{2}$ and $\mathrm{CH}_{4}$ (particularly $\mathrm{CH}_{4}$ ) content of the BMV-related waters is consistent with most mud volcanoes around the world (Etiope and Milkov, 2004). Moreover, the decreasing content of $\mathrm{CO}_{2}$ and $\mathrm{CH}_{4}$ moving (shallowing) from the BMV summit upward to the sea surface is a clear sign that the source of these dissolved gases is the BMV itself. We therefore infer that, although the BMV is not likely undergoing full mud-volcanic activity (at least during our survey in May 2017; see water backscatter data in Fig. 5b), open crustal pathways for geofluids through this structure exist and are actively venting. This hypothesis is also corroborated by the comparison with the geochemistry of three seawater columns above active fault zones in the Io- 
nian Sea (GeoC1, 2, and 3; Figs. 1 and 11). These three seawater columns are indeed characterized by a very low content of $\mathrm{CH}_{4}$ and by a content of $\mathrm{CO}_{2}$ significantly lower than that obtained for the seawater right on top of the BMV (i.e., at the BMV depth; Fig. 11).

\subsubsection{Synthesis}

Collectively, the geochemical, geophysical, and geologic data presented in this paper show that the BMV, like other onshore monitoring stations previously realized (e.g., Claesson et al., 2004; Skelton et al., 2014, 2019; Barberio et al., 2017; Huang et al., 2017), could be a proper site for installing a cabled submarine multiparametric station (Fig. 12) to study possible relationships between the seismic cycle of underlying active faults and geofluid emissions. Similar stations are active onshore in Italy, Iceland, China, and elsewhere, but, to the best of our knowledge, they have never been installed in marine settings. In the case of the BMV and other mud volcanoes, dissolved gases such as $\mathrm{CO}_{2}$ and $\mathrm{CH}_{4}$ may rather easily be monitored by submarine devices (Annunziatellis et al., 2009; Roberts et al., 2017; Boschetti et al., 2019). In particular for the seismically active Ionian Sea, many other existing mud volcanoes (Gutscher et al., 2017; Loher et al., 2018) may host a monitoring station, but the BMV is so far the one characterized by the largest geological, geophysical, and geochemical dataset and its location seems connected with seismically active faults (Fig. 2).

\section{Conclusions}

Mud volcanoes are ubiquitous structures both inland and offshore. Their occurrence is easily discernible mainly based on morphological-bathymetric evidence, but their geological significance is rather difficult to ascertain, particularly offshore. With the Bortoluzzi Mud Volcano (BMV), we have demonstrated that an integrated geological, geophysical, and geochemical study can shed much light on the geological significance and ongoing activity of a mud volcano even if located in a marine setting. We now know, for instance, that the BMV is truly a mud volcano; it sits atop seismically active faults, and its inner pathways are actively used for the rise of saline geofluids towards the Earth's surface from a depth of at least $-3000 \mathrm{~m}$. Although the paroxysmal activity of the BMV seems substantially extinct or at least quiescent, these inner pathways are open and used for the rise of geofluids more efficiently than nearby active fault zones that are usually considered efficient pathways for geofluids. This latter evidence constitutes a novelty, at least for offshore seismically active areas, and indicates that mud volcanoes could be efficiently used to install cabled stations to monitor the relationship between the seismic cycle of faults and the rise of geofluids. In particular, evidence from our work indicates that this type of station may also be installed where mud volcanoes seem extinct.

Data availability. All data used for this paper are available in numerical and graphical form in the tables and diagrams (or images), respectively, in the paper itself, or in the Supplement associated with this paper. The gravity core collected from the Ionian Sea bottom is visible at ISMAR Bologna, Italy (http://www.ismar.cnr.it/organizzazione/sedi-secondarie/bologna, last access: 15 May 2019), through the following contacts: alina.polonia@bo.ismar.cnr.it and luca.gasperini@bo.ismar.cnr.it. Two movies showing virtual flights over the BMV are available at http://www.seismofaults.it/index.php/videos (last access: 22 May 2019). With this paper, we release $4970 \mathrm{~km}^{2}$ of newly acquired (during the Seismofaults 2017 cruise) high-resolution bathymetric data in numerical form for the Ionian Sea, including the BMV (Fig. S1). This dataset (Bosman et al., 2019) is externally hosted and indexed at https://doi.org/10.5880/FIDGEO.2019.014

Supplement. The supplement related to this article is available online at: https://doi.org/10.5194/se-10-741-2019-supplement.

Author contributions. All authors actively participated in conceiving the experiment and the paper, discussing all results, contributing to the writing of the paper, drawing all figures, and drawing the conclusions. $\mathrm{ABil}$ and $\mathrm{MC}$ coordinated the experiment. $\mathrm{MC}$ and $\mathrm{ABos}$ led the fieldwork. MC, ABos, ACor, CGC, ACon, ACos, GD, GL, LG, LP, and TS participated in the Seismofaults 2017 marine campaign onboard the R/V Minerva Uno. Data were mostly processed by MC, ABos, CGC, ACon, ACor, EM, FI, GL, LP, ML, PE, TS, and $\mathrm{AP}$. The paper was mostly written by $\mathrm{AB}$ with contributions from all authors. Figures were mostly drawn by MC, ABos, CGC, ACon, EM, LP, and AP with contributions from all authors.

Competing interests. The authors declare that they have no conflict of interest.

Acknowledgements. Maurizio Barbieri, Laura Beranzoli, Francesco Frugoni, Stephen Monna, and many other colleagues from CNR, INGV, and Sapienza University of Rome are thanked for help and constructive exchanges. The officers and the crew of the R/V Minerva Uno and the scientific party of the Seismofaults 2017 survey are thanked for their cooperation during fieldwork. Spectrum Geo Ltd is thanked for granting the permit to publish the seismic profile in Fig. 10c and d. Some of the figures were produced with the Generic Mapping Tools software (http://gmt.soest.hawaii.edu, last access: 15 October 2019). We thank F. Rossetti, M. Allen, and two anonymous reviewers for their constructive comments and editorial support. The research described in this paper is dedicated to Giovanni Bortoluzzi. 
Review statement. This paper was edited by Mark Allen and reviewed by two anonymous referees.

\section{References}

Al-Balushi, A. N., Neumaier, M., Fraser, A. J., and Jackson, C. A.: The impact of the Messinian salinity crisis on the petroleum system of the Eastern Mediterranean: a critical assessment using 2D petroleum system modelling, Petrol. Geosci., 22, 357-379, https://doi.org/10.1144/petgeo2016-054, 2016.

Annunziatellis, A., Beaubien, S., Ciotoli, G., Finoia, M., Graziani, S., and Lombardi, S.: Development of an innovative marine monitoring system for $\mathrm{CO}_{2}$ leaks: system design and testing, Energy Proced., 1, 2333-2340, https://doi.org/10.1016/j.egypro.2009.01.303, 2009.

Barberio, M. D., Barbieri, M., Billi, A., Doglioni, C., and Petitta, M.: Hydrogeochemical changes before and during the 2016 Amatrice-Norcia seismic sequence (central Italy), Sci. Rep.-UK, 7, 11735, https://doi.org/10.1038/s41598-017-11990-8, 2017.

Bertelli, L., Mazzotti, A., and Persoglia, S.: Planning, acquisition and processing of the CROP seismic data: a few comments, Memorie Descrittive della Carta geologica d'Italia, 62, 47-54, 2003.

Bertoni, C. and Cartwright, J.: Messinian evaporites and fluid flow, Mar. Petrol. Geol., 66, 165-176, https://doi.org/10.1016/j.marpetgeo.2015.02.003, 2015.

Bertoni, C., Kirkham, C., Cartwright, J., Hodgson, N., and Rodriguez, K.: Seismic indicators of focused fluid flow and cross-evaporitic seepage in the Eastern Mediterranean, Mar. Petrol. Geol., 88, 472-488, https://doi.org/10.1016/j.marpetgeo.2017.08.022, 2017.

Billi, A., Funiciello, R., Minelli, L., Faccenna, C., Neri, G., Orecchio, B., and Presti, D.: On the cause of the 1908 Messina tsunami, southern Italy, Geophys. Res. Lett., 35, L06301, https://doi.org/10.1029/2008GL033251, 2008.

Billi, A., Minelli, L., Orecchio, B., and Presti, D.: Constraints to the cause of three historical tsunamis $(1908,1783$, and 1693) in the Messina Straits region, Sicily, southern Italy, Seismol. Res. Lett., 81, 907-915, https://doi.org/10.1785/gssrl.81.6.907, 2010.

Billi, A., Faccenna, C., Bellier, O., Minelli, L., Neri, G., Piromallo, C., Presti, D., Scrocca, D., and Serpelloni, E.: Recent tectonic reorganization of the Nubia-Eurasia convergent boundary heading for the closure of the western Mediterranean, Bulletin de la Société Géologique de France, 182, 279-303, https://doi.org/10.2113/gssgfbull.182.4.279, 2011.

Bortoluzzi, G., Polonia, A., Faccenna, C., Torelli, L., Artoni, A., Carlini, M., Carone, S., Carrara, G., Cuffaro, M., Del Bianco, F., D’Oriano, F., Ferrante, V., Gasperini, L., Ivaldi, R., Laterra, A., Ligi, M., Locritani, M., Muccini, F., Mussoni, P., Priore, F., Riminucci, F., Romano, S., and Stanghellini, G.: Styles and rates of deformation in the frontal accretionary wedge of the Calabrian Arc (Ionian Sea): controls exerted by the structure of the lower African plate, Ital. J. Geosci., 136, 347-364, 2017.

Boschetti, T., Barbieri, M., Barberio, M., Billi, A., Franchini, S., and Petitta, M.: $\mathrm{CO}_{2}$ inflow and element desorption prior to a seismic sequence, Amatrice-Norcia 2016, Italy, Geochem. Geophy. Geosy., in press, https://doi.org/10.1029/2018GC008117, 2019.
Bosman, A., Casalbore, D., Anzidei, M., Muccini, F., Carmisciano, C., and Chiocci, F. L.: The first ultra-high resolution Digital Terrain Model of the shallow-water sector around Lipari Island (Aeolian Islands, Italy), Ann. Geophys.-Italy, 58, S0218, https://doi.org/10.4401/ag-6746, 2015.

Bosman, A., Cuffaro, M., Conti, A., Gasperini, L., Petracchini, L., and Sgroi, T.: High-Resolution Multibeam Bathymetry along the Sicily and Calabria continental margin (Bortoluzzi Mud Volcano, Ionian Sea, Italy), GFZ, https://doi.org/10.5880/FIDGEO.2019.014, 2019.

Camerlenghi, A. and Pini, G. A.: Mud volcanoes, olistostromes and Argille scagliose in the Mediterranean region, Sedimentology, 56, 319-365, https://doi.org/10.1111/j.1365-3091.2008.01016.x, 2009.

Camerlenghi, A., Cita, M., Hieke, W., and Ricchiuto, T.: Geological evidence for mud diapirism on the Mediterranean Ridge accretionary complex, Earth Planet. Sc. Lett., 109, 493-504, https://doi.org/10.1016/0012-821X(92)90109-9, 1992.

Camerlenghi, A., Cita, M., Della Vedova, B., Fusi, N., Mirabile, L., and Pellis, G.: Geophysical evidence of mud diapirism on the Mediterranean Ridge accretionary complex, Mar. Geophys. Res., 17, 115-141, 1995.

Capozzi, R., Artoni, A., Torelli, L., Lorenzini, S., Oppo, D., Mussoni, P., and Polonia, A.: Neogene to Quaternary tectonics and mud diapirism in the Gulf of Squillace (Crotone-Spartivento Basin, Calabrian Arc, Italy), Mar. Petrol. Geol., 35, 219-234, https://doi.org/10.1016/j.marpetgeo.2012.01.007, 2012.

Capraro, L., Consolaro, C., Fornaciari, E., Massari, F., and Rio, D.: Chronology of the Middle-Upper Pliocene succession in the Strongoli area: constraints on the geological evolution of the Crotone Basin (Southern Italy), Geological Society, London, Special Publications, 262, 323-336, https://doi.org/10.1144/GSL.SP.2006.262.01.19, 2006.

Castello, B., Selvaggi, G., Chiarabba, C., and Amato, A.: CSI Catalogo della sismicità italiana 1981-2002, versione 1.1., INGVCNT, Roma, available at: https://csi.rm.ingv.it/ (last access: 15 May 2019), 2006.

Ceramicola, S., Praeg, D., Cova, A., Accettella, D., and Zecchin, M.: Seafloor distribution and last glacial to postglacial activity of mud volcanoes on the Calabrian accretionary prism, Ionian Sea, Geo-Mar. Lett., 34, 111-129, https://doi.org/10.1007/s00367013-0354-y, 2014.

Cernobori, L., Hirn, A., McBride, J. H., Nicolich, R., Petronio, L., Romanelli, M., and STREAMERS/PROFILES Working Groups: Crustal image of the Ionian basin and its Calabrian margins, Tectonophysics, 264, 175-189, https://doi.org/10.1016/S00401951(96)00125-4, 1996.

Chamot-Rooke, N., Rangin, C., Le Pichon, X., and Dotmed Working Group: Deep Offshore Tectonics of the Eastern Mediterranean: A Synthesis of Deep Marine Data in the Eastern Mediterranean: the Ionian Basin and Margins, the Calabria Wedge and the Mediterranean Ridge, Société géologique de France, 2005.

Cita, M. B., Camerlenghi, A., Erba, E., McCoy, F. W., Castradori, D., Cazzani, A., Guasti, G., Giambastiani, M., Lucchi, R., Nolli, V., Pezzi, G., Redaelli, M., Rizzi, E., Torricelli, S., and Violanti, D.: Discovery of mud diapirism on the Mediterranean ridge; a preliminary report, Bollettino della Società Geologica Italiana, 108, 537-543, 1989. 
Cita, M., Erba, E., Lucchi, R., Pott, M., Van der Meer, R., and Nieto, L.: Stratigraphy and sedimentation in the Mediterranean Ridge diapiric belt, Mar. Geol., 132, 131-150, https://doi.org/10.1016/0025-3227(96)00157-0, 1996.

Cita, M. B.: Prometheus mud breccia: an example of shale diapirism in the western Mediterranean ridge, in: Annales geologiques des Pays helleniques, 30, 543-569, 1981.

Claesson, L., Skelton, A., Graham, C., Dietl, C., Morth, M., Torssander, P., and Kockum, I.: Hydrogeochemical changes before and after a major earthquake, Geology, 32, 641-644, https://doi.org/10.1130/G20542.1, 2004.

Delisle, G., Von Rad, U., Andruleit, H., Von Daniels, C., Tabrez, A., and Inam, A.: Active mud volcanoes on-and offshore eastern Makran, Pakistan, Int. J. Earth Sci., 91, 93-110, https://doi.org/10.1007/s005310100203, 2002.

De Luca, G., Di Carlo, G., and Tallini, M.: A record of changes in the Gran Sasso groundwater before, during and after the 2016 Amatrice earthquake, central Italy, Sci. Rep.-UK, 8, 15982, https://doi.org/10.1038/s41598-018-34444-1, 2018.

Deville, E. and Guerlais, S.-H.: Cyclic activity of mud volcanoes: evidences from Trinidad (SE Caribbean), Mar. Petrol. Geol., 26, 1681-1691, https://doi.org/10.1016/j.marpetgeo.2009.03.002, 2009.

Dimitrov, L. I.: Mud volcanoes-the most important pathway for degassing deeply buried sediments, Earth-Sci. Rev., 59, 49-76, https://doi.org/10.1016/S0012-8252(02)00069-7, 2002.

Doglioni, C., Ligi, M., Scrocca, D., Bigi, S., Bortoluzzi, G., Carminati, E., Cuffaro, M., D’Oriano, F., Forleo, V., Muccini, F., and Riguzzi, F.: The tectonic puzzle of the Messina area (Southern Italy): Insights from new seismic reflection data, Sci. Rep.-UK, 2, 970, https://doi.org/10.1038/srep00970, 2012.

Etiope, G. and Milkov, A. V.: A new estimate of global methane flux from onshore and shallow submarine mud volcanoes to the atmosphere, Environ. Geol., 46, 997-1002, https://doi.org/10.1007/s00254-004-1085-1, 2004.

Evans, R. J., Stewart, S. A., and Davies, R. J.: The structure and formation of mud volcano summit calderas, J. Geol. Soc., 165, 769-780, https://doi.org/10.1144/0016-76492007-118, 2008.

Faccenna, C., Becker, T.W., Auer, L., Billi, A., Boschi, L., Brun, J.-P., Capitanio, F. A., Funiciello, F., Horvàth, F., Jolivet, L., Piromallo, C., Royden, L., Rossetti, F., and Serpelloni, E.: Mantle dynamics in the Mediterranean, Rev. Geophys., 52, 283-332, https://doi.org/10.1002/2013RG000444, 2014.

Gallais, F., Gutscher, M.-A., Klaeschen, D., and Graindorge, D.: Two-stage growth of the Calabrian accretionary wedge in the Ionian Sea (Central Mediterranean): Constraints from depthmigrated multichannel seismic data, Mar. Geol., 326, 28-45, https://doi.org/10.1016/j.margeo.2012.08.006, 2012.

Gallais, F., Graindorge, D., Gutscher, M.-A., and Klaeschen, D.: Propagation of a lithospheric tear fault (STEP) through the western boundary of the Calabrian accretionary wedge offshore eastern Sicily (Southern Italy), Tectonophysics, 602, 141-152, https://doi.org/10.1016/j.tecto.2012.12.026, 2013.

Gamberi, F. and Rovere, M.: Mud diapirs, mud volcanoes and fluid flow in the rear of the Calabrian Arc Orogenic Wedge (southeastern Tyrrhenian sea), Basin Res., 22, 452-464, https://doi.org/10.1111/j.1365-2117.2010.00473.x, 2010.

Gasperini, L. and Stanghellini, G.: SeisPrho: an interactive computer program for processing and interpretation of high- resolution seismic reflection profiles, Comput. Geosci., 35, 1497-1507, https://doi.org/10.1016/j.cageo.2008.04.014, 2009.

Gennari, G., Spezzaferri, S., Comas, M., Rüggeberg, A., Lopez-Rodriguez, C., and Pinheiro, L.: Sedimentary sources of the mud-breccia and mud volcanic activity in the Western Alboran Basin, Mar. Geol., 339, 83-95, https://doi.org/10.1016/j.margeo.2013.04.002, 2013.

Gutscher, M.-A., Dominguez, S., Mercier de Lepinay, B., Pinheiro, L., Gallais, F., Babonneau, N., Cattaneon A., Le Faou, Y., Barreca, G., Micallef, A., and Rovere, M.: Tectonic expression of an active slab tear from high-resolution seismic and bathymetric data offshore Sicily (Ionian Sea), Tectonics, 35, 39-54, https://doi.org/10.1002/2015TC003898, 2016.

Gutscher, M.-A., Kopp, H., Krastel, S., Bohrmann, G., Garlan, T., Zaragosi, S., Klaucke, I., Wintersteller, P., Loubrieu, B., Le Faou, Y., San Pedro, L., Dominguez, S., Rovere, M., Mercier de Lepinay, B., Ranero, C., and Sallares, V.: Active tectonics of the Calabrian subduction revealed by new multi-beam bathymetric data and high-resolution seismic profiles in the Ionian Sea (Central Mediterranean), Earth Planet. Sc. Lett., 461, 61-72, https://doi.org/10.1016/j.epsl.2016.12.020, 2017.

Hilton, D. R.: The helium and carbon isotope systematics of a continental geothermal system: results from monitoring studies at Long Valley caldera (California, USA), Chem. Geol., 127, 269295, https://doi.org/10.1016/0009-2541(95)00134-4, 1996.

Huang, F., Li, M., Ma, Y., Han, Y., Tian, L., Yan, W., and Li, X.: Studies on earthquake precursors in China: A review for recent 50 years, Geodesy and Geodynamics, 8, 1-12, https://doi.org/10.1016/j.geog.2016.12.002, 2017.

Huang, Q. and Ding, X.: Spatiotemporal variations of seismic quiescence prior to the 2011 M 9.0 Tohoku earthquake revealed by an improved Region-Time-Length algorithm, B. Seismol. Soc. Am., 102, 1878-1883, https://doi.org/10.1785/0120110343, 2012.

Igarashi, G., Saeki, S., Takahata, N., Sumikawa, K., Tasaka, S., Sasaki, Y., Takahashi, M., and Sano, Y.: Ground-water radon anomaly before the Kobe earthquake in Japan, Science, 269, 6061, https://doi.org/10.1126/science.269.5220.60, 1995.

Inan, S., Balderer, W. P., Leuenberger-West, F., Yakan, H., Özvan, A., and Freund, F. T.: Springwater chemical anomalies prior to the $M_{\mathrm{W}}=7.2$ Van earthquake (Turkey), Geochem. J., 46, e11e16, https://doi.org/10.2343/geochemj.1.0159, 2012.

Italiano, F., Martinelli, G., and Nuccio, P.: Anomalies of mantlederived helium during the 1997-1998 seismic swarm of Umbria-Marche, Italy, Geophys. Res. Lett., 28, 839-842, https://doi.org/10.1029/2000GL012059, 2001.

Italiano, F., Bonfanti, P., Ditta, M., Petrini, R., and Slejko, F.: Helium and carbon isotopes in the dissolved gases of Friuli region (NE Italy): geochemical evidence of $\mathrm{CO}_{2}$ production and degassing over a seismically active area, Chem. Geol., 266, 76-85, https://doi.org/10.1016/j.chemgeo.2009.05.022, 2009.

Italiano, F., Yuce, G., Uysal, I., Gasparon, M., and Morelli, G.: Insights into mantle-type volatiles contribution from dissolved gases in artesian waters of the Great Artesian Basin, Australia, Chem. Geol., 378, 75-88, https://doi.org/10.1016/j.chemgeo.2014.04.013, 2014.

King, C.-Y., Koizumi, N., and Kitagawa, Y.: Hydrogeochemical anomalies and the 1995 Kobe earthquake, Science, 269, 38-40, 1995. 
Kioka, A. and Ashi, J.: Episodic massive mud eruptions from submarine mud volcanoes examined through topographical signatures, Geophys. Res. Lett., 42, 8406-8414, https://doi.org/10.1016/j.margeo.2015.01.014, 2015.

Kirkham, C., Cartwright, J., Hermanrud, C., and Jebsen, C.: The spatial, temporal and volumetric analysis of a large mud volcano province within the Eastern Mediterranean, Mar. Petrol. Geol., 81, 1-16, https://doi.org/10.1016/j.marpetgeo.2016.12.026, 2017.

Kopf, A., Robertson, A., Clennell, M., and Flecker, R.: Mechanisms of mud extrusion on the Mediterranean Ridge Accretionary Complex, Geo-Mar. Lett., 18, 97-114, 1998.

Kopf, A. J.: Significance of mud volcanism, Rev. Geophys., 40, 152, https://doi.org/10.1029/2000RG000093, 2002.

León, R., Somoza, L., Medialdea, T., González, F., Díaz-del Río, V., Fernández-Puga, M., Maestro, A., and Mata, M.: Sea-floor features related to hydrocarbon seeps in deepwater carbonate-mud mounds of the Gulf of Cádiz: from mud flows to carbonate precipitates, Geo-Mar. Lett., 27, 237-247, https://doi.org/10.1007/s00367-007-0074-2, 2007.

Locati, M., Camassi, R., Rovida, A., Ercolani, E., Bernardini, F., Castelli, V., Caracciolo, C. H., Tertulliani, A., Rossi, A., Azzaro, R., D'Amico, S., Conte, S., and Rocchetti, E.: DBMI15, the 2015 version of the Italian Macroseismic Database. Istituto Nazionale di Geofisica e Vulcanologia, 2016.

Loher, M., Ceramicola, S., Wintersteller, P., Meinecke, G., Sahling, H., and Bohrmann, G.: Mud volcanism in a canyon: Morpho dynamic evolution of the active Venere mud volcano and its interplay with Squillace Canyon, Central Mediterranean, Geochem. Geophy. Geosy., 19, 356-378, https://doi.org/10.1002/2017GC007166, 2018.

Lupi, M., Ricci, B. S., Kenkel, J., Ricci, T., Fuchs, F., Miller, S. A., and Kemna, A.: Subsurface fluid distribution and possible seismic precursory signal at the Salse di Nirano mud volcanic field, Italy, Geophys. J. Int., 204, 907-917, https://doi.org/10.1093/gji/ggv454, 2015.

Manga, M., Brumm, M., and Rudolph, M. L.: Earthquake triggering of mud volcanoes, Mar. Petrol. Geol., 26, 1785-1798, https://doi.org/10.1016/j.marpetgeo.2009.01.019, 2009.

Martinelli, G. and Ferrari, G.: Earthquake forerunners in a selected area of Northern Italy: recent developments in automatic geochemical monitoring, Tectonophysics, 193, 397-410, https://doi.org/10.1016/0040-1951(91)90348-V, 1991.

Martinelli, G., Albarello, D., and Mucciarelli, M.: Radon emissions from mud volcanoes in Northern Italy: possible connection with local seismicity, Geophys. Res. Lett., 22, 1989-1992, https://doi.org/10.1029/95GL01785, 1995.

Mazzini, A. and Etiope, G.: Mud volcanism: an updated review, Earth-Sci. Rev., 168, 81-112, https://doi.org/10.1016/j.earscirev.2017.03.001, 2017.

Mazzini, A., Svensen, H., Akhmanov, G., Aloisi, G., Planke, S., Malthe-Sørenssen, A., and Istadi, B.: Triggering and dynamic evolution of the LUSI mud volcano, Indonesia, Earth Planet. Sc. Lett., 261, 375-388, https://doi.org/10.1016/j.eps1.2007.07.001, 2007.

Milkov, A. V.: Global estimates of hydrate-bound gas in marine sediments: how much is really out there?, Earth-Sci. Rev., 66, 183197, https://doi.org/10.1016/j.earscirev.2003.11.002, 2004.
Minelli, L. and Faccenna, C.: Evolution of the Calabrian accretionary wedge (central Mediterranean), Tectonics, 29, TC4004, https://doi.org/10.1029/2009TC002562, 2010.

Onda, S., Sano, Y., Takahata, N., Kagoshima, T., Miyajima, T., Shibata, T., Pinti, D. L., Lan, T., Kim, N. K., Kusakabe, M., and Nishio Y.: Groundwater oxygen isotope anomaly before the M6. 6 Tottori earthquake in Southwest Japan, Sci. Rep.-UK, 8, 4800, https://doi.org/10.1038/s41598-018-23303-8, 2018.

Orecchio, B., Presti, D., Totaro, C., and Neri, G.: What earthquakes say concerning residual subduction and STEP dynamics in the Calabrian Arc region, south Italy, Geophys. J. Int., 199, 19291942, https://doi.org/10.1093/gji/ggu373, 2014.

Palano, M., Ferranti, L., Monaco, C., Mattia, M., Aloisi, M., Bruno, V., Cannavò, F., and Siligato, G.: GPS velocity and strain fields in Sicily and southern Calabria, Italy: updated geodetic constraints on tectonic block interaction in the central Mediterranean, J. Geophys. Res.-Sol. Ea., 117, B07401, https://doi.org/10.1029/2012JB009254, 2012.

Palano, M., Schiavone, D., Loddo, M., Neri, M., Presti, D., Quarto, R., Totaro, C., and Neri, G.: Active upper crust deformation pattern along the southern edge of the Tyrrhenian subduction zone (NE Sicily): Insights from a multidisciplinary approach, Tectonophysics, 657, 205-218, https://doi.org/10.1016/j.tecto.2015.07.005, 2015.

Panieri, G., Polonia, A., Lucchi, R., Zironi, S., Capotondi, L., Negri, A., and Torelli, L.: Mud volcanoes along the inner deformation front of the Calabrian Arc accretionary wedge (Ionian Sea), Mar. Geol., 336, 84-98, https://doi.org/10.1016/j.margeo.2012.11.003, 2013.

Patacca, E. and Scandone, P.: The 1627 Gargano earthquake (Southern Italy): identification and characterization of the causative fault, J. Seismol., 8, 259-273, https://doi.org/10.1023/B:JOSE.0000021393.77543.1e, 2004.

Petitta, M., Mastrorillo, L., Preziosi, E., Banzato, F., Barberio, M. D., Billi, A., Cambi, C., De Luca, G., Di Carlo, P., Di Curzio, D., Di Salvo, C., Nanni, T., Palpacelli, S., Rusi, S., Saroli, M., Tallini, M., Tazioli, A., Valigi, D., Vivalda, P., and Doglioni, C.: Watertable and discharge changes associated with the 2016-2017 seismic sequence in central Italy: hydrogeological data and a conceptual model for fractured carbonate aquifers, Hydrogeol. J., 26, 1-18, https://doi.org/10.1007/s10040-017-1717-7, 2018.

Planke, S., Svensen, H., Hovland, M., Banks, D., and Jamtveit, B.: Mud and fluid migration in active mud volcanoes in Azerbaijan, Geo-Mar. Lett., 23, 258-268, https://doi.org/10.1007/s00367003-0152-z, 2003.

Polonia, A., Torelli, L., Mussoni, P., Gasperini, L., Artoni, A., and Klaeschen, D.: The Calabrian Arc subduction complex in the Ionian Sea: Regional architecture, active deformation, and seismic hazard, Tectonics, 30, TC5018, https://doi.org/10.1029/2010TC002821, 2011.

Polonia, A., Torelli, L., Gasperini, L., and Mussoni, P.: Active faults and historical earthquakes in the Messina Straits area (Ionian Sea), Nat. Hazards Earth Syst. Sci., 12, 2311-2328, https://doi.org/10.5194/nhess-12-2311-2012, 2012.

Polonia, A., Torelli, L., Artoni, A., Carlini, M., Faccenna, C., Ferranti, L., Gasperini, L., Govers, R., Klaeschen, D., Monaco, C., Neri, G., Nijholt, N., Orecchio, B., and Wortel, R.: The Ionian and Alfeo-Etna fault zones: New segments of an evolving plate 
boundary in the central Mediterranean Sea?, Tectonophysics, 675, 69-90, https://doi.org/10.1016/j.tecto.2016.03.016, 2016.

Polonia, A., Nelson, C., Romano, S., Vaiani, S., Colizza, E., Gasparotto, G., and Gasperini, L.: A depositional model for seismo-turbidites in confined basins based on Ionian Sea deposits, Mar. Geol., 384, 177-198, https://doi.org/10.1016/j.margeo.2016.05.010, 2017.

Praeg, D., Ceramicola, S., Barbieri, R., Unnithan, V., and Wardell, N.: Tectonically-driven mud volcanism since the late Pliocene on the Calabrian accretionary prism, central Mediterranean Sea, Mar. Petrol. Geol., 26, 1849-1865, https://doi.org/10.1016/j.marpetgeo.2009.03.008, 2009.

Roberts, J. J., Gilfillan, S. M., Stalker, L., and Naylor, M.: Geochemical tracers for monitoring offshore $\mathrm{CO}_{2}$ stores, Int. J. Greenh. Gas Con., 65, 218-234, https://doi.org/10.1016/j.ijggc.2017.07.021, 2017.

Robertson, A.: Mud volcanism on the Mediterranean Ridge: Initial results of ocean drilling program Leg 160, Geology, 24, 239-242, https://doi.org/10.1130/00917613(1996)024<0239:MVOTMR>2.3.CO;2, 1996.

Römer, M., Sahling, H., Pape, T., dos Santos Ferreira, C., Wenzhöfer, F., Boetius, A., and Bohrmann, G.: Methane fluxes and carbonate deposits at a cold seep area of the Central Nile Deep Sea Fan, Eastern Mediterranean Sea, Mar. Geol., 347, 27-42, https://doi.org/10.1016/j.margeo.2013.10.011, 2014.

Rossi, S. and Sartori, R.: A seismic reflection study of the external Calabrian Arc in the northern Ionian Sea (eastern Mediterranean), Mar. Geophys. Res., 4, 403-426, 1981.

Rovere, M., Gamberi, F., Mercorella, A., Rashed, H., Gallerani, A., Leidi, E., Marani, M., Funari, V., and Pini, G. A.: Venting and seepage systems associated with mud volcanoes and mud diapirs in the southern Tyrrhenian Sea, Mar. Geol., 347, 153-171, https://doi.org/10.1016/j.margeo.2013.11.013, 2014.

Sano, Y. and Wakita, H.: Precise measurement of helium isotopes in terrestrial gases, B. Chem. Soc. Jpn., 61, 1153-1157, 1988.

Sano, Y., Takahata, N., Kagoshima, T., Shibata, T., Onoue, T., and Zhao, D.: Groundwater helium anomaly reflects strain change during the 2016 Kumamoto earthquake in Southwest Japan, Sci. Rep.-UK, 6, 37939, https://doi.org/10.1038/srep37939, 2016.

Scrocca, D., Doglioni, C., and Innocenti, F.: Constraints for an interpretation of the Italian geodynamics: a review, Memorie Descrittive della Carta Geologica d Italia, 62, 15-46, 2003a.

Scrocca, D., Doglioni, C., Innocenti, F., Manetti, P., Mazzotti, A., Bertelli, L., Burbi, L., and D'Offizi, S.: CROP ATLAS-Seismic Reflection Profiles of the Italian Crust, vol. 62, CROP ATLAS, $2003 b$.

Sella, P., Billi, A., Mazzini, I., De Filippis, L., Pizzino, L., Sciarra, A., and Quattrocchi, F.: A newly-emerged (August 2013) artificially-triggered fumarole near the Fiumicino airport, Rome, Italy, J. Volcanol. Geoth. Res., 280, 53-66, https://doi.org/10.1016/j.jvolgeores.2014.05.008, 2014.

Serpelloni, E., Vannucci, G., Pondrelli, S., Argnani, A., Casula, G., Anzidei, M., Baldi, P., and Gasperini, P.: Kinematics of the Western Africa-Eurasia plate boundary from focal mechanisms and GPS data, Geophys. J. Int., 169, 1180-1200, https://doi.org/10.1111/j.1365-246X.2007.03367.x, 2007.

Skelton, A., Claesson, L., Chakrapani, G., Mahanta, C., Routh, J., Mörth, M., and Khanna, P.: Coupling between seismic activity and hydrogeochemistry at the Shillong Plateau,
Northeastern India, Pure Appl. Geophys., 165, 45-61, https://doi.org/10.1007/s00024-007-0288-2, 2008.

Skelton, A., Andrén, M., Kristmannsdóttir, H., Stockmann, G., Mörth, C. M., Sveinbjörnsdóttir, A., Jónsson, S., Sturkell, E., Guðrúnardóttir, H. R., Hjartarson, H., Siegmund, H., and Kockum, I.: Changes in groundwater chemistry before two consecutive earthquakes in Iceland, Nat. Geosci., 7, 752-756, https://doi.org/10.1038/NGEO2250, 2014.

Skelton, A., Liljedahl-Claesson, L., Wästeby, N., Andrén, M., Stockmann, G., Sturkell, E., Mörth, C.-M., Stefansson, A., Tollefsen, E., Siegmund, H., Keller, N., Kjartansdóttir, R., Hjartarson, H., and Kockum, I.: Hydrochemical changes before and after earthquakes based on long term measurements of multiple parameters at 2 sites in northern Iceland-a review, J. Geophys. Res.-Sol. Ea., 2702-2720, https://doi.org/10.1029/2018JB016757, 2019.

Somoza, L., Leon, R., Diaz del Rio, V., Ivanov, M., FernandezPuga, M., Lobato, A., Maestro, A., Pinheiro, L., HernandezMolina, F., Rodero, J., Vazquez, J., and Medialtea, T.: Seabed morphology and hydrocarbon seepage in the Gulf of Cadiz mud volcano area: Acoustic imagery, multibeam and ultrahigh resolution seismic data, Mar. Geol., 195, 153-176, https://doi.org/10.1016/S0025-3227(02)00686-2, 2003.

Somoza, L., Medialdea, T., León, R., Ercilla, G., Vázquez, J. T., Hernández-Molina, J., González, J., Juan, C., FernándezPuga, M. C.: Structure of mud volcano systems and pockmarks in the region of the Ceuta Contourite Depositional System (Western Alborán Sea), Mar. Geol., 332, 4-26, https://doi.org/10.1016/j.margeo.2012.06.002, 2012.

Staffini, F., Spezzaferri, S., and Aghib, F.: Mud diapirs of the Mediterranean Ridge: sedimentological and micropaleontological study of the mud breccia, Rivista Italiana di Paleontologia e Stratigrafia (Research In Paleontology and Stratigraphy), 99, 225-254, 1993.

Totaro, C., Presti, D., Billi, A., Gervasi, A., Orecchio, B., Guerra, I., and Neri, G.: The ongoing seismic sequence at the Pollino Mountains, Italy, Seismol. Res. Lett., 84, 955-962, https://doi.org/10.1785/0220120194, 2013.

Tung, S. and Masterlark, T.: Delayed poroelastic triggering of the 2016 October Visso earthquake by the August Amatrice earthquake, Italy, Geophys. Res. Lett., 45, 2221-2229, https://doi.org/10.1002/2017GL076453, 2018.

Valensise, G. and Pantosti, D.: A 125 Kyr-long geological record of seismic source repeatability: the Messina Straits (southern Italy) and the 1908 earthquake (Ms 7 1/2), Terra Nova, 4, 472-483, https://doi.org/10.1111/j.1365-3121.1992.tb00583.x, 1992.

van der Meer, R.: Grading in mud volcanic breccia from the Mediterranean Ridge, Mar. Geol., 132, 165-173, https://doi.org/10.1016/0025-3227(95)00159-X, 1996.

Wakita, H., Nakamura, Y., and Sano, Y.: Short-term and intermediate-term geochemical precursors, Pure Appl. Geophys., 126, 267-278, 1988.

Wortel, M. and Spakman, W.: Subduction and slab detachment in the Mediterranean-Carpathian region, Science, 290, 1910-1917, https://doi.org/10.1126/science.290.5498.1910, 2000. 